\title{
The effects of nitrate on the heterogeneous uptake of sulfur dioxide on hematite
}

\author{
L. D. Kong, X. Zhao, Z. Y. Sun, Y. W. Yang, H. B. Fu, S. C. Zhang, T. T. Cheng, X. Yang, L. Wang, and J. M. Chen \\ Shanghai Key Laboratory of Atmospheric Particle Pollution and Prevention, Department of Environmental Science \\ \& Engineering, Fudan University, Shanghai 200433, China
}

Correspondence to: L. D. Kong (ldkong@fudan.edu.cn) and J. M. Chen (jmchen@fudan.edu.cn)

Received: 31 March 2014 - Published in Atmos. Chem. Phys. Discuss.: 8 May 2014

Revised: 13 July 2014 - Accepted: 1 August 2014 - Published: 10 September 2014

\begin{abstract}
Nitrate is often found to be associated with atmospheric particles. Surface nitrate can change the hygroscopicity of these particles, and thus impact their chemical reactivity. However, the influence of nitrate on heterogeneous reactions of atmospheric trace gases is poorly understood. In this work, the effects of nitrate on heterogeneous conversion of $\mathrm{SO}_{2}$ with hematite at $298 \mathrm{~K}$ are investigated using an in situ diffuse reflectance infrared Fourier transform spectroscopy (DRIFTS) and a White cell coupled with Fourier transform infrared spectroscopy (White cell-FTIR). It is found that nitrate participates in heterogeneous reactions of $\mathrm{SO}_{2}$, accelerates the formation rate of sulfate, and leads to the formation of surface-adsorbed $\mathrm{HNO}_{3}$ and gas-phase $\mathrm{N}_{2} \mathrm{O}$ and HONO. The results indicate that low to moderate amounts of nitrate significantly enhance the reactivity of hematitenitrate mixtures, the uptake of $\mathrm{SO}_{2}$, and the formation of sulfate on hematite. For mixtures, the sample containing $24 \%$ nitrate exhibits the highest sulfate formation rate, and its corresponding uptake coefficient calculated by geometric surface area is about 5.5 times higher than that of hematite alone. The sample containing $48 \%$ nitrate presents the highest Brunauer-Emmett-Teller (BET) uptake coefficient, and the value is about 8 times higher than that of pure hematite. No uptake of $\mathrm{SO}_{2}$ and formation of sulfate are observed on pure nitrate. Evidence presented herein implies a significant contribution of the unreleased $\mathrm{HNO}_{3}$ and $\mathrm{HONO}$ in the particles for the conversion of $\mathrm{SO}_{2}$ and the enhanced formation of sulfate in the atmosphere. A possible mechanism for the influence of nitrate on the heterogeneous conversion of $\mathrm{SO}_{2}$ on hematite is proposed, and atmospheric implications based on these results are discussed.
\end{abstract}

\section{Introduction}

Sulfur dioxide is a major component of air pollution. It is usually generated by the combustion of fossil fuels and by the atmospheric oxidation of biogenic organic sulfur compounds, particularly dimethyl sulfide. The oxidation of sulfur dioxide leads to sulfate particulate formation. Atmospheric sulfate particles play significant roles in adverse health effects, visibility degradation, and rain water acidification (Seinfeld and Pandis, 2006). The conversion of $\mathrm{SO}_{2}$ to sulfate in the atmosphere usually occurs via three well-known pathways, including gas-phase oxidation to sulfuric acid followed by condensation into the particulate phase, aqueous-phase oxidation in cloud and fog droplets, and various heterogeneous reactions on the surfaces of aerosol particles (Kerminen et al., 2000). There have been a number of atmospheric chemistry models applied to predict the formation of sulfate aerosols on a global scale (Kasibhatla et al., 1997; Laskin et al., 2003). The results suggest that atmospheric $\mathrm{SO}_{2}$ concentrations are typically overestimated, while sulfate concentrations tend to be underestimated (Kasibhatla et al., 1997; Laskin et al., 2003), and the two pathways including gaseous oxidation by $\mathrm{OH}$ radical and aqueous oxidation in cloud and fog droplets by ozone and hydrogen peroxide are insufficient to bridge the gap between field and modeling studies (Luria and Sievering, 1991). Including in-cloud oxidation catalyzed by natural transition metal ions in models will improve agreement between models and observations (Harris et al., 2013). These imply that the heterogeneous conversion of $\mathrm{SO}_{2}$ to sulfate on aerosols may make an important contribution to the atmospheric sulfate concentration, or there are some unknown pathways for the formation of sulfate in the troposphere. As a result, the heterogeneous oxidation of $\mathrm{SO}_{2}$ to 
sulfate on aerosols has been receiving increasing attention in recent years. To date there have been a lot of studies regarding heterogeneous reactions of $\mathrm{SO}_{2}$ on various model oxides and mineral dust particles (Dentener et al., 1996; Goodman et al., 2001; Usher et al., 2002; Ullerstam et al., 2003; Baltrusaitis et al., 2007; Lin et al., 2010; Zhu et al., 2011; Wu et al., 2011; Liu et al., 2012). However, the atmospheric heterogeneous reactions of $\mathrm{SO}_{2}$ still have large uncertainties (Laskin et al., 2003), and the underlying mechanisms of sulfate formation on mineral aerosols are not completely understood (Dentener et al., 1996). For example, in the atmosphere, the heterogeneous reactions of $\mathrm{SO}_{2}$ are unavoidably affected by other atmospheric species, but little attention has been paid to the effects of other species on the heterogeneous reaction of $\mathrm{SO}_{2}$ in the laboratory studies up to now (Ullerstam et al., 2003; Lin et al., 2010; Wu et al., 2011; Liu et al., 2012).

Mineral dust aerosol, emitted from the arid and semiarid regions with a global source strength of about 1000$3000 \mathrm{Tg} \mathrm{yr}^{-1}$, is one of the most important contributors to the airborne particulate matter (Dentener et al., 1996). It is now widely recognized that mineral dust aerosols provide reactive surfaces for atmospheric trace gases, and the reactions on mineral dust particles change their sizes and optical and hygroscopic properties, as well as lifetime in the atmosphere, which in turn can change the climate impact of these particles. Mineral oxide represents an important and reactive component of mineral dust aerosol. Being one of the typical oxide minerals, $\mathrm{Fe}_{2} \mathrm{O}_{3}$ contributes $\sim 6 \%$ by mass to the total dust burden in the atmosphere (Usher et al., 2003). Atmospheric chemical processing of Fe-containing dust particles during long-range transport can impact the amount of soluble iron (Zhuang et al., 1992; Meskhidze et al., 2003), while soluble iron will limit phytoplankton primary productivity in extensive regions of the ocean referred to as highnutrient low-chlorophyll regions (Moore et al., 2002), which ultimately has implications for global climate as well as carbon and nitrogen cycles (Jickells and Spokes, 2001). Thus, there is interest in the atmospheric chemistry of $\mathrm{Fe}_{2} \mathrm{O}_{3}$. On the other hand, field studies have also observed that nitrate is one of the most common components of secondary particles. It is often found to be associated with these mineral dust particles in the atmosphere (Dentener et al., 1996). Surface nitrate enhances hygroscopic properties of original particles and in turn changes their physicochemical properties (Hoffman et al., 2004). This will inevitably impact their chemical reactivity, and therefore lead to a remarkable difference in their heterogeneous chemistry. However, little attention has been paid to the influence of nitrate on heterogeneous reactions of $\mathrm{SO}_{2}$ on atmospheric aerosols up to now (Lin et al., 2010).

In the present study, the effects of nitrate on heterogeneous conversions of $\mathrm{SO}_{2}$ on mineral particles at room temperature are investigated using an in situ diffuse reflectance infrared Fourier transform spectroscopy (DRIFTS) and a White cell coupled with Fourier transform infrared spectroscopy (White
cell-FTIR). Hematite ( $\alpha-\mathrm{Fe}_{2} \mathrm{O}_{3}$, one of the typical components in mineral aerosol) and sodium nitrate (a major form of nitrate in sea-salt particles) were used as model components of particles. The heterogeneous conversion mechanism of $\mathrm{SO}_{2}$ is proposed, and atmospheric implications of the present study are discussed. The results reveal a potential pathway of sulfate formation in the troposphere and the significant contribution of particulate nitrate for the conversion of $\mathrm{SO}_{2}$ and the enhanced formation of sulfate in the atmosphere.

\section{Experimental}

\subsection{Materials}

Hematite was prepared according to the procedure reported previously (Schwertmann and Cornell, 2000). Powder X-ray diffraction confirmed the prepared sample as pure hematite (Fig. S1 in the Supplement). The Brunauer-Emmett-Teller (BET) surface area was $12.1 \mathrm{~m}^{2} \mathrm{~g}^{-1}$ (Micromeritics TriS$\operatorname{tar}$ 3000, Micromeritics Instrument Co., USA.). Sodium nitrate (analytical grade, Shanghai Ab Chem Co. Ltd.) was used without further purification. Gaseous oxygen, argon (99.999\% purity, Shanghai Yunguang Specialty Gases Inc.), and $\mathrm{SO}_{2}\left(97 \mathrm{ppm}, \mathrm{SO}_{2} / \mathrm{N}_{2}\right.$, Shanghai Yunguang Specialty Gases Inc.) were introduced through an air dryer before use.

In order to systematically study the effects of nitrate on heterogeneous reactions of $\mathrm{SO}_{2}$ with atmospheric aerosols, a series of hematite-sodium nitrate mixtures with the mass fractions of sodium nitrate in the mixtures in the range of $2-90 \%(w / w)$ (denoted as FN-2, FN-6, .., FN-90, respectively) were prepared. Hematite was impregnated with a saturated aqueous solution of sodium nitrate, and then the mixtures were stirred manually and dried under an infrared lamp. Considering that aerosol particles in the real atmosphere invariably contain surface-adsorbed water and that the surfaceadsorbed water plays an important role in the heterogeneous chemistry of atmospheric $\mathrm{SO}_{2}$, all of the prepared samples were kept in a desiccator at $68 \%$ relative humidity $(\mathrm{RH})$ for $48 \mathrm{~h}$ before further use. Powder X-ray diffraction indicated that no secondary processes occurred on the hematite surface during the sample preparation and the subsequent sample equilibration (see Fig. S1 in the Supplement). The humid samples including the hematite-nitrate mixtures, pure hematite, and nitrate were still loose, fine powders after the equilibration, and this treatment caused some adsorbed water molecule layers to be present on the samples.

\subsection{In situ DRIFTS experiments}

In situ DRIFTS spectra were recorded using a Nicolet Avatar 360 FTIR spectrometer, equipped with a high-sensitivity mercury cadmium telluride (MCT) detector and a SpectraTech diffuse reflectance accessory, as described previously (Fu et al., 2007; also see Fig. S2 in the Supplement). The DRIFTS sample cell is coupled with a temperature controller. 
A $30 \mathrm{mg}$ sample was placed into the ceramic sample holder in the in situ chamber, and the sample temperature controller was used to control reaction temperature. Before the reaction gas was introduced, the reaction chamber was purged with argon $\left(100 \mathrm{~mL} \mathrm{~min}^{-1}\right)$ for $1 \mathrm{~h}$, and then a background spectrum of the unreacted powder sample was collected. Subsequently, a mixture of $\mathrm{SO}_{2}$ (e.g., $\left.3 \mathrm{ppm}\right)$ and $\mathrm{O}_{2}(21 \% v / v)$ with argon as a carrier was introduced into the chamber at a total flow rate of $100 \mathrm{~mL} \mathrm{~min}^{-1}$, and then IR spectra were collected as a function of reaction time. The total reaction time is about 4-6 h. All spectra reported here were recorded at a resolution of $4 \mathrm{~cm}^{-1}$ for 100 scans. All of the measurements were repeated three times. In addition, it should be pointed out that weak surface water loss was observed during the purge and subsequent reaction processes. This implies that some water molecules are kept in the sample due to the presence of hygroscopic salt $\left(\mathrm{NaNO}_{3}\right)$.

\subsection{In situ White cell-FTIR experiments}

An infrared cell (White cell reactor, model 19-V, a variablepath long-path cell with the optical path length from 2.4 to $24 \mathrm{~m}$; Infrared Analysis Inc.) coupled to a Fourier transform infrared spectrometer was used to measure trace gaseous reactants and the possible gaseous products formed from the heterogeneous reaction of $\mathrm{SO}_{2}$. The optical path length was set to the maximum for all of the measurements. The infrared cell was cleaned with ultrapure water and then dried before every experiment. The infrared cell was connected to a vacuum system and a gas supply system. The apparatus has been described in detail elsewhere (Fu et al., 2007; Zhang et al., 2006; also see Fig. S3 in the Supplement). For in situ FTIR measurements, the experiments were conducted in the absence of light. The infrared cell was flushed with pure argon with the aid of the vacuum system, and this cleaning process was repeated three times before a sample was placed into the infrared cell. A $30 \mathrm{mg}$ sample was placed in a small reaction disk (inner diameter: $1 \mathrm{~cm}$; depth: $0.1 \mathrm{~cm}$ ) made of quartz, and then the disk was placed into the infrared cell. After the sample was placed, argon was filled into the cell again to $1.01 \times 10^{5} \mathrm{~Pa}$, the background spectrum of the gases was collected, and then the infrared cell was evacuated to $20 \mathrm{~Pa}$ again. Argon was used as a carrier gas to load the reactive gases $\mathrm{SO}_{2}$ and $\mathrm{O}_{2}$ into the infrared cell through the gas supply system. After the infrared cell was filled to a pressure of $1.01 \times 10^{5} \mathrm{~Pa}$, it remained at that pressure for $3 \mathrm{~min}$ to ensure homogeneous mixing of the gases in the infrared cell before starting to collect the in situ IR spectra. FTIR spectra were recorded using a Nicolet Avatar 360 FTIR equipped with a liquid-nitrogen-cooled MCT detector. One hundred repeat spectral scans were averaged over a range of $600-4000 \mathrm{~cm}^{-1}$ at a spectral resolution of $4 \mathrm{~cm}^{-1}$. A single-beam spectrum collected prior to the $\mathrm{SO}_{2}$ exposure was used as the reference spectrum. In order to trace gaseous products, a long reaction time (up to $20 \mathrm{~h}$ ) was adopted in some experiments. The peak areas of the characteristic peaks of $\mathrm{SO}_{2}$ have a linear correlation with the concentration of $\mathrm{SO}_{2}\left(R^{2}>0.999\right)$. Thus, the concentration of gaseous $\mathrm{SO}_{2}$ can be determined by measuring the corresponding in situ FTIR spectra peak areas of gaseous $\mathrm{SO}_{2}$. All of the measurements were repeated at least twice.

\subsection{Heterogeneous reaction of $\mathrm{SO}_{2}$ in the dark}

Heterogeneous reactions of $\mathrm{SO}_{2}(50 \mathrm{ppm})$ on humid hematite, $\mathrm{FN}-24$ and FN-90 were performed in the presence of $\mathrm{O}_{2}(21 \% \mathrm{v} / \mathrm{v})$ in three $42 \mathrm{~mL}$ brown glass bottles in the dark at room temperature for about 3-7 days, respectively. An about $30 \mathrm{mg}$ sample, which was kept in a desiccator at $68 \% \mathrm{RH}$ for $48 \mathrm{~h}$, was placed flatly on the bottom of the glass bottle in order to make sure that no sample particles were stuck on the interior wall of the glass bottle. Before the reaction gas $\mathrm{SO}_{2}$ was introduced, a mixture of $\mathrm{Ar}$ and $\mathrm{O}_{2}$ $(21 \% \mathrm{v} / \mathrm{v})$ was introduced into the bottle at a total flow rate of $100 \mathrm{~mL} \mathrm{~min}^{-1}$ to expel air from the bottle for an hour, after which the inlet and the outlet of the bottle were closed. Then $2.1 \mu \mathrm{L}$ of $\mathrm{SO}_{2}(50 \mathrm{ppm})$ was injected through the septum into the bottle with a microsyringe. After the above treatments, the final amount of water in the bottle should be close to that in the same sample in the DRIFTS cell. The bottle was packed in aluminum foil and then placed in the dark for 3-7 days.

\subsection{Ion analysis and $\mathrm{N}_{2} \mathrm{O}$ detection}

The products formed on the sample surface were analyzed by means of ion chromatography after DRIFTS experiments. The method is similar to that in a previous study (Ullerstam et al., 2002). The reacted sample particles were extracted by sonication with ultrapure water (specific resistance $\geq 18.0 \mathrm{M} \Omega \mathrm{cm}$ ). The leaching solution contained $1 \%$ formaldehyde as a preservative to suppress sulfite oxidation and was obtained through a $0.45 \mu \mathrm{m}$ PTFE membrane filter. The filtered solution was analyzed using a Dionex DX 500 ion chromatography, which was equipped with a Dionex AS 14 analytical column and a CD20 conductivity detector. A weak base eluent $\left(1.0 \mathrm{mM} \mathrm{NaHCO}_{3}-3.5 \mathrm{mM} \mathrm{Na}_{2} \mathrm{CO}_{3}\right)$ was used for anion detection at a flow rate of $1.5 \mathrm{~mL} \mathrm{~min}^{-1}$. Quality assurance of species measurement was routinely carried out by using standard reference materials produced by the National Research Center for Certified Reference Materials, China.

A solid-phase microextraction-gas chromatography-mass spectrometry (SPME/GC-MS) method was also used to detect nitrous oxide (Drescher et al., 2006). SPME was carried out using a commercial SUPELCO $75 \mu \mathrm{m}$ Carboxen/PDMS fiber to qualitatively analyze $\mathrm{N}_{2} \mathrm{O}$. Before the fiber was used for the first time, it was conditioned at $280^{\circ} \mathrm{C}$ until a clean chromatogram was obtained under normal run conditions. In addition, to minimize background signals, the fibers were 
heated in the GC inlet for 2 to $5 \mathrm{~min}$ before each sampling. The SPME fiber was directly inserted in the White cell reactor or brown glass bottle for $30 \mathrm{~min}$ at room temperature for the collection of gas-phase $\mathrm{N}_{2} \mathrm{O}$. The analysis was performed using a GC-MS (Agilent, USA) fused-silica capillary column (HP-5MS, J \& W Scientific, Folsom, CA, USA; $30 \mathrm{~m} \times 0.25 \mathrm{~mm}$ I.D., $0.25 \mu \mathrm{m}$ film thickness). The carrier gas was high-purity helium $\left(99.999 \%, 1.0 \mathrm{~mL} \mathrm{~min}^{-1}\right)$. The mass spectrometer was operated in the electron ionization (EI) mode at the electron energy of $70 \mathrm{eV}$. Thermal desorption of retained compounds on fiber was carried out at $260^{\circ} \mathrm{C}$ in splitless mode. A blank analysis was performed prior to running a sample analysis.

\section{Results and discussion}

\subsection{Effect of nitrate on surface species formed from the uptake of $\mathrm{SO}_{2}$ onto hematite}

In situ DRIFTS experiments were carried out on humid hematite, pure nitrate, and a series of hematite-sodium nitrate mixtures with $2-90 \%$ of mass fractions of nitrate, respectively. Each experiment was performed at $298 \mathrm{~K}$ with $30 \mathrm{mg}$ of sample to investigate the effects of nitrate on the uptake of gas-phase $\mathrm{SO}_{2}$ onto the sample particle surface and the nature of the formed surface-bound species.

\subsubsection{Surface sulfur-containing species}

Figure 1a shows the in situ DRIFT spectra of surface species produced on pure hematite after exposure to $\mathrm{SO}_{2}$. Four prominent peaks at $1261,1219,1158$, and $1056 \mathrm{~cm}^{-1}$ and three weak shoulder peaks at 1361,1337 , and $1000 \mathrm{~cm}^{-1}$ are readily observed in the spectra. The intensities of these peaks increase as the reaction proceeds. These peaks can be assigned to adsorbed bisulfate and/or sulfate on the particle surface based on assignments in previous studies (Yamaguchi et al., 1986; Watanabe et al., 1994; Persson and Lovgren, 1996; Hug, 1997; Sugimoto and Wang, 1998; Nanayakkara et al., 2012). Watanabe et al. (1994) observed infrared absorption peaks at $1360,1270,1150$, and $1020 \mathrm{~cm}^{-1}$ for the sulfated hematite at $25^{\circ} \mathrm{C}$, and suggested that the peak at $1270 \mathrm{~cm}^{-1}$ was assigned to the symmetric stretching vibration mode of $\mathrm{S}=\mathrm{O}$ and the peak at $1150 \mathrm{~cm}^{-1}$ was assigned to the asymmetric stretching vibration mode of $\mathrm{S}-\mathrm{O}$. A transmission FTIR study on $\mathrm{SO}_{2}$ reacted $\mathrm{TiO}_{2}$ surface has also shown peaks at 1361, 1297, 1172,1116, 1050, and $1000 \mathrm{~cm}^{-1}$, which were assigned to adsorbed sulfate species. The peak at $1335 \mathrm{~cm}^{-1}$ was also observed by Nanayakkara et al. (2012) and was thought to be most likely due to the formation of sulfate. Therefore, in the present study, the prominent peaks at $1261,1158,1056$, and $1000 \mathrm{~cm}^{-1}$ reflect the formation of adsorbed sulfate. Additionally, peak fitting using a combination of Lorentzian and Gaussian line shapes to deconvolute overlapping peaks of every single spectrum of an experiment shows that the peaks at 1261 and $1158 \mathrm{~cm}^{-1}$ simultaneously increase in intensity as the reaction time increases, while the peak at $1219 \mathrm{~cm}^{-1}$ shows a completely different behavior (see Fig. S4 in the Supplement). The peak at $1219 \mathrm{~cm}^{-1}$ rapidly grows in the early stage of the reaction, reaches a plateau, and then slightly decreases in intensity as the reaction proceeds, implying that the peak at $1219 \mathrm{~cm}^{-1}$ should be assigned to different surface species and this species undergoes secondary chemistry on the sample surface. Faguy and Marinković (1996) studied the structure of bisulfate and sulfate adsorbed on the $\mathrm{Pt}$ (111) surface via potential difference Fourier transform infrared spectroscopy and found that a maximum at $1227-1250 \mathrm{~cm}^{-1}$ was consistent with adsorbed bisulfate or adsorbed sulfate- $\mathrm{H}_{3} \mathrm{O}^{+}$ternary complexes on the $\mathrm{Pt}$ (111) electrode surface. Hug (1997) found that a peak at or above $1200 \mathrm{~cm}^{-1}$ appeared after drying of a hematite layer treated with sulfate at $\mathrm{pH} 3.6$ or with hematite in contact with aqueous sulfate solutions acidified to below $\mathrm{pH} 2$ with $\mathrm{HCl}$. He suggested that the conversion of aqueous sulfate to bisulfate occurred during acidification, and thus the peak around $1200 \mathrm{~cm}^{-1}$ was assigned to the transformation from monodentate to bidentate coordination caused by drying or to the formation of bisulfate. Sugimoto and Wang (1998) further revealed that the adsorption mode of sulfate changed from monodentate to bidentate with decreasing $\mathrm{pH}$ and that the bidentate adsorption on $\{012\}$ and $\{1 \mathrm{~m} 0\}$ surfaces of hematite became dominant at $\mathrm{pH} \leq 1.0$, and they suggested that the enhancement of the peak at $1205 \mathrm{~cm}^{-1}$ with direct drying of a wet sample at $\mathrm{pH}$ 3.6, found by Hug (1997), seemed to be due to the $\mathrm{pH}$ drop during the drying process. The attribution of the peak at around $1200 \mathrm{~cm}^{-1}$ remains controversial; however, the appearance of this peak undoubtedly reflects the enhancement of surface acidity. Therefore, in the present study, the increase in the peak intensity at $1219 \mathrm{~cm}^{-1}$ with the increase in reaction time indicates the increased surface acidity (Yamaguchi et al., 1986; Persson and Lovgren, 1996; Faguy and Marinković, 1996; Hug, 1997). The slight decrease in intensity of the peak at $1219 \mathrm{~cm}^{-1}$ after it reaches the maximum may be due to partial dissolution of hematite along with consumption of surface acidic species, which would lead to the formation of $\mathrm{Fe}^{3+}$ ions and some other surface species on the water-containing surface (Chun and Quon, 1973; Shi et al., 2011).

Figure $1 \mathrm{~b}$ shows typical spectra of the oxidation of $\mathrm{SO}_{2}$ on FN-24 recorded as a function of time in the range of 1500 to $900 \mathrm{~cm}^{-1}$. A prominent peak at $1158 \mathrm{~cm}^{-1}$, a shoulder peak at $1190 \mathrm{~cm}^{-1}$, and two weak peaks at 1080 and $987 \mathrm{~cm}^{-1}$ are observed in the spectra. These peaks can be assigned to surface-coordinated sulfate species, i.e., bidentate surface sulfate complexes (Zhang et al., 2006; Persson and Lovgren, 1996; Hug, 1997; Peak et al., 1999). Additionally, it is also possible that the feature at $1190 \mathrm{~cm}^{-1}$ is assigned to bisulfate $\left(\mathrm{HSO}_{4}^{-}\right)$or sodium sulfate $\left(\mathrm{NaSO}_{4}^{-}\right)$sorbed as a monodentate complex on the iron oxide surface, or monodentate sulfate that is hydrogen-bonded to an adjacent surface 
site (Hug, 1997; Peak et al., 1999). In addition, $\mathrm{Fe}^{3+}$ ions are present due to the partial dissolution of hematite in the water-containing acidic surface during the reaction (Chun and Quon, 1973; Shi et al., 2011), and an iron (III) bisulfate complex $\left(\mathrm{Fe}-\mathrm{HSO}_{4}^{2+}\right)$ can also potentially explain the observed feature at $1190 \mathrm{~cm}^{-1}$ (Peak et al., 1999). These results indicate that $\mathrm{SO}_{2}$ can also be oxidized to sulfate on the surface of the hematite-nitrate mixture. The spectrum line shapes are different from those of hematite, and the most apparent FTIR feature corresponding to the increase in surface product on FN-24 is the rapidly growing peak at $1158 \mathrm{~cm}^{-1}$, indicating that the adsorbed sulfate is the dominant oxidation product. Therefore, $\mathrm{NO}_{3}^{-}$ions in the nitrate-hematite mixture promote the heterogeneous uptake of $\mathrm{SO}_{2}$ and impact the formation of surface species and the adsorption mode of the formed surface species. A spectral peak-fitting program using mixed Gaussian-Lorentzian peak fitting is employed to fit peaks to the last spectrum in Fig. 1b. As shown in Fig. 2, the region from 1400 to $900 \mathrm{~cm}^{-1}$ is composed of three major peaks at 1207,1155 and $1094 \mathrm{~cm}^{-1}$, respectively. A very weak peak at $986 \mathrm{~cm}^{-1}$ cannot even be seen in Fig. 2 . The relative intensity of the observed peaks at 1207,1155 , 1094 , and $986 \mathrm{~cm}^{-1}$ is approximately $5.6: 16.1: 2.2: 0.1$, respectively. The presence of the peak at $1207 \mathrm{~cm}^{-1}$ indicates that the FN-24 surface after the experiment is still acidic. Moreover, compared with that of the hematite-only substrate (see Sect. S6 in the Supplement), weak absorption peaks at 1080,1050 , and $966 \mathrm{~cm}^{-1}$ appear in the initial stage of heterogeneous conversion of $\mathrm{SO}_{2}$ and then gradually disappear or are not easily observed with increased exposure time. These peaks should be assigned to the stretching motion of adsorbed sulfite and/or bisulfite (Zhang et al., 2006). The changes in intensity of these weak absorption peaks implies that the formation of $\mathrm{SO}_{3}^{2-}$ and/or $\mathrm{HSO}_{3}^{-}$and their subsequently rapid consumption on the particle surface. The rapidly growing peak at $1158 \mathrm{~cm}^{-1}$ as the reaction proceeds also suggests that $\mathrm{SO}_{3}^{2-}$ and $\mathrm{HSO}_{3}^{-}$are further oxidized in the presence of nitrate and less $\mathrm{SO}_{3}^{2-}$ and $\mathrm{HSO}_{3}^{-}$are left when compared with that of the hematite-only substrate.

\subsubsection{Surface nitrogen-containing species}

It should be noted that, compared to the peaks of the formed surface-adsorbed sulfate, some very low intensity signals appear in the region of 3800 to $1350 \mathrm{~cm}^{-1}$ during the same experiment with FN-24 (also see Fig. S5 in the Supplement). Figure 3 shows DRIFTS spectra following $\mathrm{SO}_{2}$ uptake on FN-24 particles as a function of reaction time in this region. Negative peaks at 1599,1587 , and $1567 \mathrm{~cm}^{-1}$ decrease in intensity with increased exposure time. These peaks are assigned to bridging, bidentate, and monodentate nitrate, respectively (Hixson et al., 2011; Underwood et al., 1999). This indicates the loss of adsorbed nitrate on FN-24 and suggests that nitrate not only participates in the heterogeneous conversion of $\mathrm{SO}_{2}$ on $\mathrm{FN}-24$ but also has been consumed during

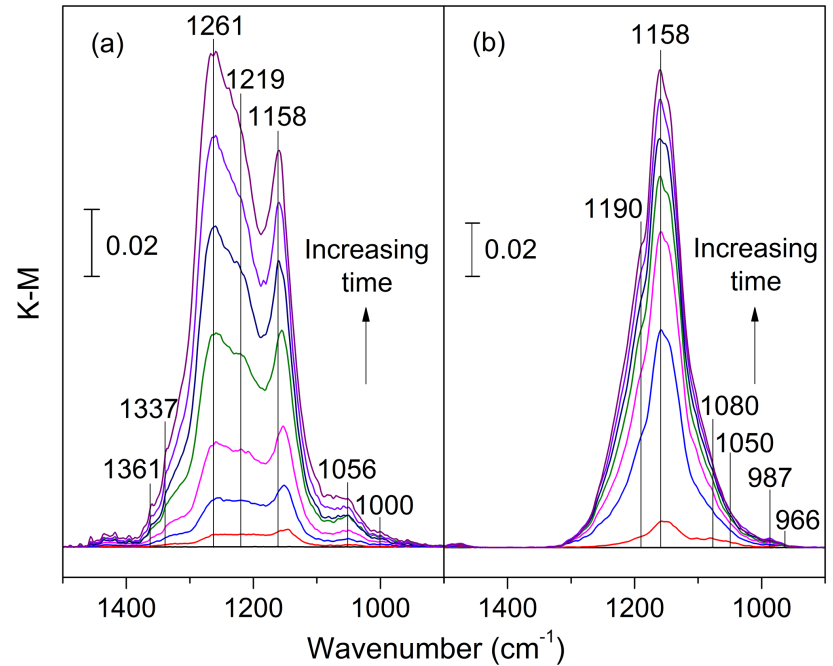

Figure 1. DRIFT spectra of different samples recorded upon exposure to $\mathrm{SO}_{2}$ at $298 \mathrm{~K}$. (a) Hematite. (b) FN-24.

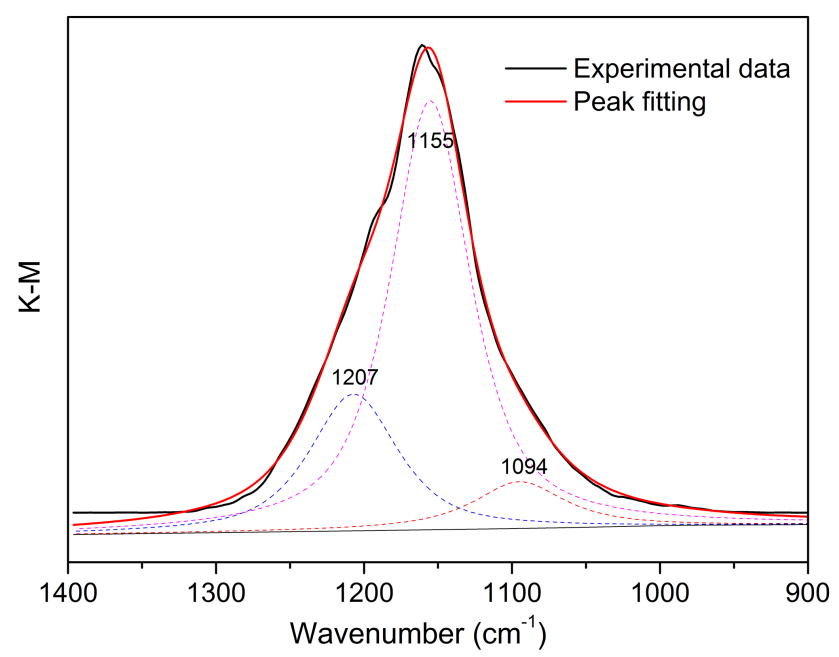

Figure 2. Peak fitting of the last DRIFT spectrum of the products on FN-24 shown in Fig. 1 by mixed Gaussian-Lorentzian peak fitting.

the reaction. This result is consistent with the formation of nitrogen-containing species such as $\mathrm{N}_{2} \mathrm{O}$ and HONO (discussed later in Sect. 3.4). However, it should be pointed out that the amount of the decay of nitrate is small during the reaction, which also results in small amounts of $\mathrm{N}_{2} \mathrm{O}$ and HONO.

Several weak peaks in the $1535-1440 \mathrm{~cm}^{-1}$ region grow with increasing exposure time. These peaks can be assigned to adsorbed nitrite. The peaks at 1506 and $1487 \mathrm{~cm}^{-1}$ are assigned to the $\nu_{3}$ mode of bridging nitro-nitrito $\mathrm{NO}_{2}^{-}$and the $v_{3}$ mode of bridging monodentate nitrito $\mathrm{NO}_{2}^{-}$, respectively, suggesting the formation of very small amounts of nitrite (Hixson et al., 2011). 


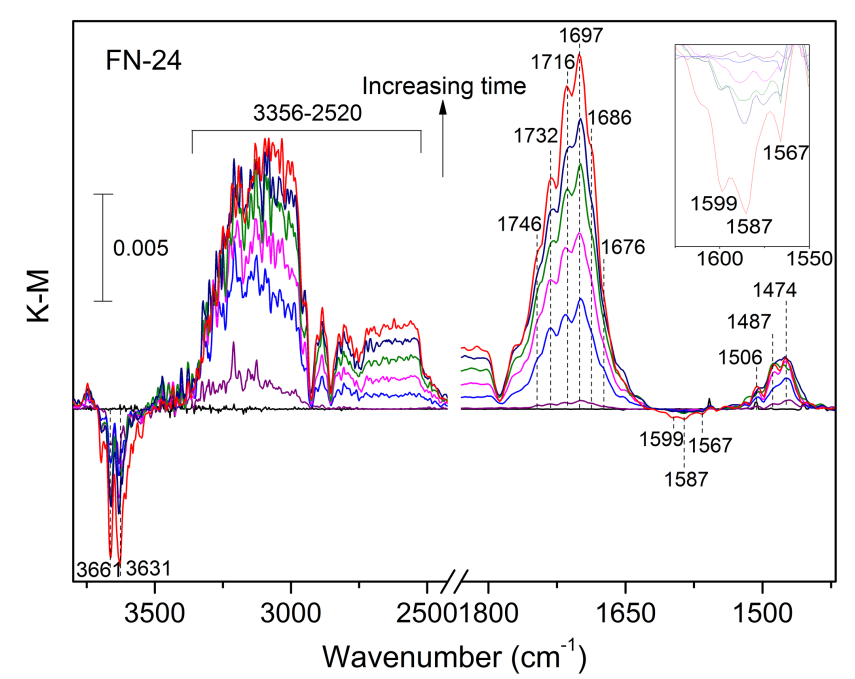

Figure 3. DRIFT spectra of FN-24 as a function of time after exposure to $\mathrm{SO}_{2}$ in the range of 3800 to $1350 \mathrm{~cm}^{-1}$. The inset shows expanded region from 1630 to $1550 \mathrm{~cm}^{-1}$.

Molecularly adsorbed nitric acid and different nitric acidwater complexes, characterized by the peaks at 1716, 1697, 1686, and $1676 \mathrm{~cm}^{-1}$ (McCurdy et al., 2002; Ramazan et al., 2006; Finlayson-Pitts et al., 2003), are also observed. These peaks are ascribed to the $\nu_{2}$ mode of the asymmetric $\mathrm{NO}_{2}$ stretch in nitric acid (monomer or when complexed to water or another $\mathrm{HNO}_{3}$ ) (McCurdy et al., 2002; Ramazan et al., 2006; Finlayson-Pitts et al., 2003), and the peaks at $1716,1697,1686$, and $1676 \mathrm{~cm}^{-1}$ are due to $\mathrm{HNO}_{3} \cdot\left(\mathrm{H}_{2} \mathrm{O}\right)_{n}$, $\mathrm{HNO}_{3} \cdot \mathrm{H}_{2} \mathrm{O},\left(\mathrm{HNO}_{3}\right)_{2}$, and $\mathrm{HNO}_{3} \cdot\left(\mathrm{H}_{2} \mathrm{O}\right)_{2}$ on the surface, respectively. These peaks increase in intensity with increased exposure time. This result confirms that adsorbed $\mathrm{HNO}_{3}$ is formed from the combination of surface $\mathrm{H}^{+}$with $\mathrm{NO}_{3}^{-}$as the reaction proceeds. The formation of $\mathrm{HNO}_{3}-\mathrm{H}_{2} \mathrm{O}$ complexes indicates that nitric acid is stabilized by water on the particle surface (McCurdy et al., 2002; Ramazan et al., 2006; Finlayson-Pitts et al., 2003). As a result, no gas-phase $\mathrm{HNO}_{3}$ was observed in White cell-FTIR experiments as discussed later. Compared to the assignments of molecularly adsorbed nitric acid, molecular nitric acid complexed to water, and molecular nitric acid complexed to $\mathrm{HNO}_{3}$ itself in previous reports, these peaks have blue shifted by about $6 \mathrm{~cm}^{-1}$ (McCurdy et al., 2002; Ramazan et al., 2006), indicating that the asymmetric $\mathrm{NO}_{2}$ stretch in nitric acid may be affected by some other interaction, and the interaction may result in the distortion of the molecular symmetry of these complexes (Peak et al., 1999).

Two weak shoulder peaks at 1746 and $1732 \mathrm{~cm}^{-1}$ are seen to grow as the surface is exposed to $\mathrm{SO}_{2}$. These two peaks should be attributed to the asymmetric $v_{\mathrm{a}}\left(\mathrm{NO}_{2}\right)$ stretch of $\mathrm{N}_{2} \mathrm{O}_{4}$ adsorbed on the surface, indicating the formation of adsorbed $\mathrm{N}_{2} \mathrm{O}_{4}$ (Koch et al., 1995; Goodman et al., 1999; Finlayson-Pitts et al., 2003). These peaks overlap with those of adsorbed $\mathrm{HNO}_{3}$ and increase in intensity with the amount of adsorbed nitric acid on the surface. As previously reported, $\mathrm{N}_{2} \mathrm{O}_{4}$ can interact with $\mathrm{HNO}_{3}$ and/or $\mathrm{HNO}_{3}-\mathrm{H}_{2} \mathrm{O}$ complexes on particle surface through hydrogen bonds, in addition to the interactions with $\mathrm{H}_{2} \mathrm{O}$ (Finlayson-Pitts et al., 2003). This further indicates that the formed $\mathrm{N}_{2} \mathrm{O}_{4}$ may be held on a particle surface with nitric acid and $\mathrm{H}_{2} \mathrm{O}$ present. This is consistent with the fact that no gas-phase $\mathrm{N}_{2} \mathrm{O}_{4}$ was detected in White cell-FTIR experiments, as discussed later. Surface $\mathrm{N}_{2} \mathrm{O}_{4}$, which can oxidize many organic and inorganic compounds, was observed as the crucial oxidant for the oxidation of surface sulfite (Liu et al., 2012). Therefore, the presence of a very small amount of $\mathrm{N}_{2} \mathrm{O}_{4}$ on a particle surface may contribute to the oxidation of surface sulfite and the formation of sulfate and adsorbed nitrite.

\subsubsection{Surface hydroxyl groups}

Two negative absorption peaks are observed at 3661 and $3631 \mathrm{~cm}^{-1}$, and they grow in intensity as the reaction proceeds. These negative peaks have been previously reported and attributed to the loss of $\mathrm{OH}$ groups from the surface. The peaks at 3661 and $3631 \mathrm{~cm}^{-1}$ are stretching vibration modes of isolated surface hydroxyl groups bonded to the surface iron ions of octahedral sites and tetrahedral sites, respectively (Watanabe et al., 1994), which implies that surface OH groups are involved in the reaction and are reaction active sites for $\mathrm{SO}_{2}$ (Goodman et al., 2001). Pure hematite shows similar absorption. Another weak broad absorption peak extending from 3500 to $2520 \mathrm{~cm}^{-1}$ slowly increases in intensity with the increase in reaction time. This broad peak is primarily associated with $\mathrm{O}-\mathrm{H}$ vibration of hydrogen-bonded $\mathrm{OH}$ groups of acid and should be assigned to molecular nitric acid complexed to water or to some extent complexed to $\mathrm{HNO}_{3}$ itself (Börensen et al., 2000; Goodman, et al., 1999; Ramazan et al., 2006; Finlayson-Pitts et al., 2003), which is consistent with the formation of surface-adsorbed $\mathrm{HNO}_{3}$ discussed earlier.

Overall, the results indicate that nitrate participates in the heterogeneous reactions of $\mathrm{SO}_{2}$; changes the conversion pathway of $\mathrm{SO}_{2}$ and the formation rate of sulfate; and leads to the formation of surface $\mathrm{HNO}_{3}, \mathrm{~N}_{2} \mathrm{O}_{4}$, and $\mathrm{NO}_{2}^{-}$species. A summary of the assignments for the surface species peaks observed in this study based on frequencies reported in earlier studies is given in Table 1.

\subsection{Effect of nitrate on the rate of sulfate formation and uptake coefficient for $\mathrm{SO}_{2}$ on hematite-nitrate mixture at $298 \mathrm{~K}$}

The formation rates of sulfate on different samples were investigated. All of the DRIFTS experiments were performed at $298 \mathrm{~K}$ with $30 \mathrm{mg}$ of sample, and the amount of sulfate on each sample after DRIFTS experiment was determined via ion chromatography to quantify the sulfate formation rate 
Table 1. Assignment of vibrational frequencies of surface species formed on hematite particle surfaces and on hematite-nitrate mixtures surfaces.

\begin{tabular}{lll}
\hline Surface species & $\begin{array}{l}\text { Hematite } \\
\left(\mathrm{cm}^{-1}\right)\end{array}$ & $\begin{array}{l}\text { Hematite-nitrate mixture } \\
\left(\mathrm{cm}^{-1}\right)\end{array}$ \\
\hline $\mathrm{SO}_{3}^{2-} / \mathrm{HSO}_{3}^{-}$ & 1056 & $1080,1050,966$ \\
$\mathrm{SO}_{4}^{2-}$ & $1361,1337,1261$, & $1158,1190,987$ \\
& $1158,1056,1000$ & \\
Acidic species & 1219 & $1599,1587,1567$ \\
$\mathrm{NO}_{3}^{-}$ & & 1506,1487 \\
$\mathrm{NO}_{2}^{-}$ & & $1676,1686,1697,1716$ \\
Adsorbed $\mathrm{HNO}_{3}$ & & 3664,3631 \\
\hline
\end{tabular}

$\mathrm{d}\left[\mathrm{SO}_{4}^{2-}\right] / \mathrm{d} t$. It is found that, over a large concentration range, the integrated sulfate absorption (1000 to $1400 \mathrm{~cm}^{-1}$ ) is proportional to the sulfate concentration. The formation rate is therefore translated from the integrated sulfate absorbance of the spectrum to the total number of sulfate ions on the sample after the reaction by a conversion factor. The conversion factor is obtained from a calibration plot with integrated sulfate absorption vs. number of sulfate ions formed at the end of

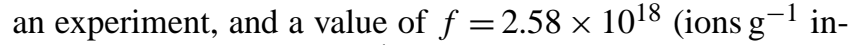
tegrated absorption units ${ }^{-1}$ ) is calculated. Since the absorption peaks of different reaction product species overlap one another, the peaks were deconvoluted before integration in some experiments.

The gas-phase concentrations of the reactive gases in a continuous flow were kept constant during the DRIFTS experiments, and since $\mathrm{O}_{2}$ was in great excess compared to $\mathrm{SO}_{2}$, the concentration of $\mathrm{O}_{2}$ could be regarded as constant. The number of sulfate ions formed at the initial stage of reaction is generally considered to be small relative to the number of reactive surface sites, and thus the latter at initial stage can be assumed to be constant (Börensen, et al., 2000). Therefore, the reaction order can be determined from a bilogarithmic plot of initial rate of sulfate formation $\left(\log \left(\mathrm{d}\left[\mathrm{SO}_{4}^{2-}\right] / \mathrm{d} t\right)\right)$ vs. the concentration of $\mathrm{SO}_{2}\left(\log \left[\mathrm{SO}_{2}\right]\right)$, as previously reported (Börensen et al., 2000; Wu et al., 2011). For this purpose, the experiments with different $\mathrm{SO}_{2}$ concentrations were performed, and the sulfate formation rate $\mathrm{d}\left[\mathrm{SO}_{4}^{2-}\right] / \mathrm{d} t$ was obtained from the slope of the initial linear portion $(0$ $60 \mathrm{~min}$ ) in the curve of sulfate formation as a function of time. No saturation effects on sulfate formation were observed. For a mixture such as FN-24 used in this study, the plot gave a slope of $1.09 \pm 0.10(2 \sigma)$, which indicates a reaction order of 1 for $\mathrm{SO}_{2}$. The reaction order with respect to $\mathrm{SO}_{2}$ was also examined from White cell-FTIR experimental data by examining the rates of $\mathrm{SO}_{2}$ decay. The calculated result is consistent with that using DRIFTS data (the correlation coefficient of $\ln \left[\mathrm{SO}_{2}\right]_{0} /\left[\mathrm{SO}_{2}\right]$ vs. time $(t)$ was greater than 0.99). That is, the heterogeneous oxidation of $\mathrm{SO}_{2}$ on the hematite-nitrate mixture was still a pseudo-first-order reaction.

The reactive uptake coefficient $(\gamma)$ is defined as the rate of sulfate formation on the surface $\left(\mathrm{d}\left[\mathrm{SO}_{4}^{2-}\right] / \mathrm{d} t\right)$ divided by the total number of surface collisions per unit time $(Z)$.

$$
\begin{aligned}
\gamma & =\frac{\mathrm{d}\left[\mathrm{SO}_{4}^{2-}\right] / \mathrm{d} t}{Z}, \\
Z & =\frac{1}{4} \times A_{\mathrm{s}} \times\left[\mathrm{SO}_{2}\right] \times v, \\
\nu & =\sqrt{8 \mathrm{RT} / \pi M_{\mathrm{SO}_{2}}},
\end{aligned}
$$

where $v$ is the mean molecular velocity of $\mathrm{SO}_{2}, A_{\mathrm{s}}$ is the effective sample surface, $R$ is the gas constant, $T$ is the temperature, and $M_{\mathrm{SO}_{2}}$ is the molecular weight of $\mathrm{SO}_{2}$ (Ullerstam, et al., 2003). Two extreme cases of effective sample surface are usually considered for calculating the uptake coefficient (Ullerstam et al., 2002). If the reaction probability is high, the reactants would have no time to diffuse into the sample before reacting and the effective surface area would thus be the geometric surface area of the sample holder $\left(A_{\text {geometric }}\right)$. If the reaction probability is low, the reactants may have enough time to diffuse into the entire sample, and thus the BET surface area $\left(A_{\mathrm{BET}}\right)$ would more appropriately represent the effective area. Therefore, upper and lower limits of uptake coefficients can be calculated using the geometric and BET surface area as the reactive surface area, respectively (denoted as $\gamma_{\text {geometric }}$ and $\gamma_{\mathrm{BET}}$, respectively).

Table 2 shows the sulfate formation rates and the two kinds of uptake coefficients of $\mathrm{SO}_{2}$ on hematite and the hematitenitrate mixtures at $298 \mathrm{~K}$. The sulfate formation rate and the two kinds of uptake coefficients first increase and then decrease with increasing mass fraction of nitrate, and no sulfate formation is observed on pure sodium nitrate. For mixtures, the FN-24 sample presents the highest sulfate formation rate. Correspondingly, the FN-24 sample shows the highest $\gamma_{\text {geometric }}$, and its $\gamma_{\text {geometric }}$ is about 5.5 times higher than that of hematite alone. Although the sulfate formation rate for FN-24 is higher than that for FN-48, the BET uptake coefficient $\gamma_{\mathrm{BET}}$ for FN-24 is less than that for FN-48. This is mainly because that the FN-48 has smaller BET surface area than the $\mathrm{FN}-24$, and hence the $\mathrm{FN}-48$ presents the highest $\gamma_{\mathrm{BET}}$. Its $\gamma_{\mathrm{BET}}$ is about 8 times higher than that of pure hematite. Therefore, the reaction behavior of $\mathrm{SO}_{2}$ adsorbed on hematite is altered by the availability of nitrate. An appropriate amount of nitrate greatly enhances the reactivity of the hematite-nitrate mixtures and favors the formation of sulfate on hematite. The promotion effect of a low to moderate amount of nitrate should receive close attention because the nitrate content is close to that in ambient particles (Ho et al., 2003), and this effect may help to predict the formation of sulfate aerosols in the atmosphere. 
Table 2. Sulfate formation rates and uptake coefficients for heterogeneous reactions of $\mathrm{SO}_{2}$ on hematite and the hematite-nitrate mixtures at $298 \mathrm{~K}$.

\begin{tabular}{|c|c|c|c|c|c|}
\hline $\begin{array}{c}\mathrm{NaNO}_{3} \\
(\%)\end{array}$ & $\begin{array}{c}A_{\mathrm{BET}} \\
\left(\mathrm{m}^{2} \mathrm{~g}^{-1}\right)\end{array}$ & $\begin{array}{l}\text { Sulfate formation rate } \\
\left.\text { (ions s}^{-1}\right)\left(\times 10^{15}\right)\end{array}$ & $\begin{array}{c}A_{\text {geometric }} \\
\left(\mathrm{m}^{2}\right)\left(\times 10^{5}\right)\end{array}$ & $\begin{array}{c}\gamma_{\mathrm{BET}} \\
\left(\times 10^{7}\right)\end{array}$ & $\begin{array}{c}\gamma_{\text {geometric }} \\
\left(\times 10^{3}\right)\end{array}$ \\
\hline 0 & 12.1 & $1.28 \pm 0.07$ & 7.85 & $5.58 \pm 0.29$ & $2.58 \pm 0.14$ \\
\hline 2 & 11.8 & $1.48 \pm 0.15$ & 7.85 & $6.60 \pm 0.69$ & $2.98 \pm 0.31$ \\
\hline 4 & 11.7 & $2.01 \pm 0.12$ & 7.85 & $9.04 \pm 0.56$ & $4.04 \pm 0.25$ \\
\hline 6 & 11.5 & $3.62 \pm 0.18$ & 7.85 & $16.6 \pm 0.81$ & $7.29 \pm 0.35$ \\
\hline 12 & 10.9 & $4.93 \pm 0.29$ & 7.85 & $23.8 \pm 0.14$ & $9.93 \pm 0.58$ \\
\hline 24 & 9.1 & $7.11 \pm 1.34$ & 7.85 & $41.2 \pm 0.78$ & $14.3 \pm 2.69$ \\
\hline 48 & 5.2 & $4.39 \pm 0.39$ & 7.85 & $44.5 \pm 0.39$ & $8.84 \pm 0.78$ \\
\hline 60 & 4.0 & $1.62 \pm 0.25$ & 7.85 & $21.3 \pm 0.32$ & $3.25 \pm 0.49$ \\
\hline 72 & 2.8 & $0.59 \pm 0.15$ & 7.85 & $11.2 \pm 0.29$ & $1.19 \pm 0.31$ \\
\hline 90 & 1.3 & $0.15 \pm 0.03$ & 7.85 & $6.10 \pm 1.05$ & $0.30 \pm 0.05$ \\
\hline 100 & & 0 & & 0 & 0 \\
\hline
\end{tabular}

\subsection{Effect of nitrate on heterogeneous reactivity of $\mathrm{SO}_{2}$ on hematite at $298 \mathrm{~K}$}

White cell-FTIR can be used to trace gaseous reactants and possible gaseous products formed from the heterogeneous reaction of $\mathrm{SO}_{2}$, but it cannot be used to observe surface species formed on the sample surface. In situ White cellFTIR spectra collected from exposure of the FN-24 sample to $50 \mathrm{ppm}$ of $\mathrm{SO}_{2}$ at room temperature are shown in Fig. 4. The strong absorption peaks at 1373,1360 , and $1348 \mathrm{~cm}^{-1}$ and the weak ones at 1163 and $1135 \mathrm{~cm}^{-1}$ are readily observed in the spectra. These peaks are assigned to the characteristic peaks of gaseous $\mathrm{SO}_{2}$ (Fu et al., 2007; Zhang et al., 2006). The intensities of these peaks in the spectra decrease rapidly as the reaction proceeds, indicating that the concentration of $\mathrm{SO}_{2}$ decreases while it reacts on the surface of FN-24. The other FN series and pure hematite samples upon exposure to $50 \mathrm{ppm}$ of $\mathrm{SO}_{2}$ at room temperature show similar absorption but different rates of $\mathrm{SO}_{2}$ consumption, revealing that the sample reactivity varies with mass fractions of sodium nitrate. No uptake of $\mathrm{SO}_{2}$ is observed on the pure sodium nitrate. The results indicate that the reactivity increases first and then decreases with increasing mass fraction of sodium nitrate in the samples. This is consistent with that observed in DRIFTS experiments.

\subsection{Effect of nitrate on gas-phase products from the het- erogeneous uptake of $\mathrm{SO}_{2}$ on hematite}

It is worth noting that several absorption peaks of gaseous HONO appear in the spectra in the White cell-FTIR experiment by exposing the FN series samples to lower concentrations of $\mathrm{SO}_{2}$. Although adsorbed $\mathrm{HNO}_{3}$ has been detected during the DRIFTS experiments, gas-phase nitric acid has not been observed in White cell-FTIR experiments, suggesting that molecular nitric acid is firmly adsorbed on the particle surface in the presence of water. Figure 5 shows the representative in situ FTIR spectra collected from exposure of the

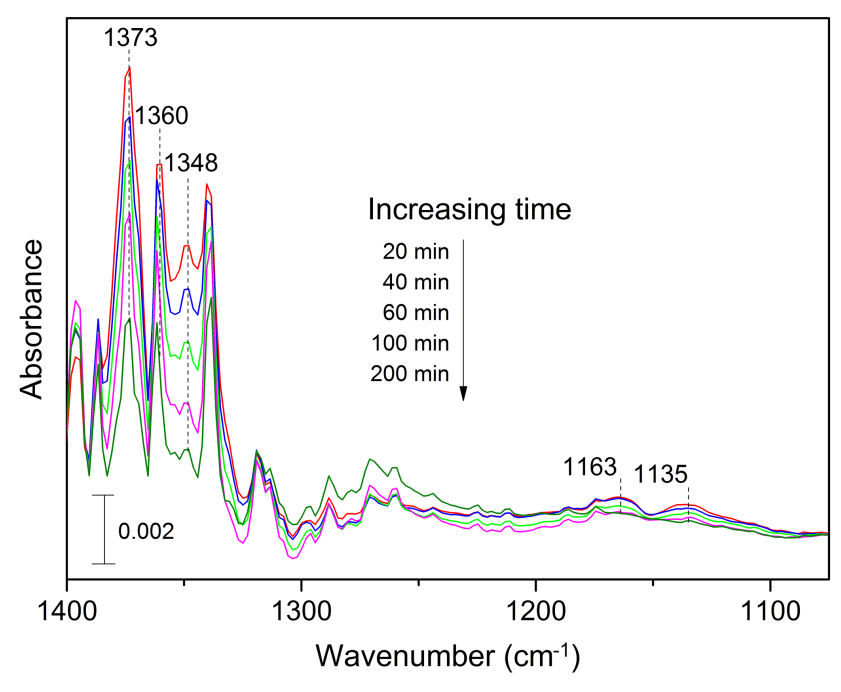

Figure 4. In situ White cell-FTIR spectra of FN-24 recorded upon exposure to $50 \mathrm{ppm} \mathrm{SO}_{2}+21 \% \mathrm{O}_{2}$ at room temperature for different reaction times.

FN-90 sample to 12.5 ppm of $\mathrm{SO}_{2}$ for different times. A difference spectrum shown in Fig. 5e was obtained by subtracting the spectrum in Fig. 5c from that in Fig. 5d. As shown in Fig. 5, there are no absorption peaks of gas-phase HONO before $430 \mathrm{~min}$, but several weak HONO absorption peaks centered at 1262,850 , and $790 \mathrm{~cm}^{-1}$ are observed when the reaction time is prolonged to $1170 \mathrm{~min}$ (Fig. 5d) (Wingen et al., 2000). The difference spectrum shown in Fig. 5e further confirms the existence of HONO, revealing that a trace amount of gaseous $\mathrm{HONO}$ is formed during the reaction of $\mathrm{SO}_{2}$ on the hematite-nitrate mixture. To the best of our knowledge, this is the first observation of the formation of HONO in such a nitrate-containing reaction system. Observation of HONO formation is of particular significance because it plays an important role in the degradation of primary and secondary atmospheric pollutants by serving as a 
major source of hydroxyl radicals. HONO formed from heterogeneous reaction of nitrogen dioxide has been extensively studied on different materials like mineral dust particles and soot (Finlayson-Pitts et al., 2003; Arens et al., 2001), and $\mathrm{HONO}$ is known to be in equilibrium with $\mathrm{NO}$ and $\mathrm{NO}_{2}$ in the gas phase via its self-reaction (Pitts et al., 1984). However, the heterogeneous reaction of nitrogen dioxide and the self-reaction of HONO may be negligible in our system because no absorption peaks of gas-phase $\mathrm{NO}$ and $\mathrm{NO}_{2}$ in the spectral range from 1200 to $1900 \mathrm{~cm}^{-1}$ are observed. It is possible that gaseous $\mathrm{NO}$ and $\mathrm{NO}_{2}$ are present at concentrations below detection limits. But, on the other hand, the weak absorption peaks of HONO may suggest the very low HONO partial pressure, and hence the self-reaction of HONO is probably not relevant at such a low HONO pressure.

The result also suggests that the initial surface-formed HONO may be simultaneously consumed by some secondary reactions in this system. On the one hand, no absorption peaks of HONO by exposing the FN series samples to $50 \mathrm{ppm} \mathrm{SO}_{2}$ for the same reaction time were observed. This fact suggests that the possible consumption reactions of HONO may be the ones between HONO and the surface abundant reduced $\mathrm{S}$ (IV) species, such as sorbed or surfacecoordinated $\mathrm{H}_{2} \mathrm{SO}_{3}, \mathrm{HSO}_{3}^{-}$, and $\mathrm{SO}_{3}^{2-}$ species, which led to gaseous HONO levels below detection limits before the complete consumption of these species. On the other hand, the high concentration of $\mathrm{SO}_{2}$ means that there are much more reduced $\mathrm{S}$ (IV) species existing on the sample surface than those formed from the low concentration of $\mathrm{SO}_{2}$. This also implies that $\mathrm{HONO}$ will be observed within a long reaction time if the high concentration of $\mathrm{SO}_{2}$ is used. An earlier study of Martin et al. (1981) observed that S (IV) species can be rapidly oxidized to sulfate by HONO in acidic aqueous aerosols, which would support the secondary reactions of HONO with S (IV) species in our experiments and reveal the potential role of $\mathrm{HONO}$ in the heterogeneous conversion of $\mathrm{SO}_{2}$. In addition, the absorption peaks between 1400 and $1800 \mathrm{~cm}^{-1}$ are mainly attributed to $\mathrm{H}_{2} \mathrm{O}$ molecule vibrations. These absorption peaks gradually grow in intensity with the increase in reaction time because $\mathrm{H}_{2} \mathrm{O}$ molecules can evaporate slowly from the humid surface of FN samples placed in the White cell.

Rivera-Figueroa et al. (2003) found that the reaction between $\mathrm{HNO}_{3}$ and $\mathrm{SO}_{2}$ on silica surfaces in the presence of water films does not occur. Martin et al. (1981) also reported that nitric acid in solution does not react with dissolved $\mathrm{SO}_{2}$. Furthermore, in our study the experiments in which humid pure nitrate was exposed to $\mathrm{SO}_{2}$ using White cell-FTIR and DRIFTS techniques also show no detectable gas-phase products, indicating that pure nitrate cannot interact with $\mathrm{SO}_{2}$. Therefore, considering the species in the reaction systems mentioned above, these previous studies indicate that the reactions between $\mathrm{HNO}_{3}$ and $\mathrm{S}$ (IV) species cannot occur. Moreover, reductive dissolution of Fe (III) oxides and reduction of Fe (III) by sulfite have been suggested as possible sources of Fe (II) (Behra and Sigg, 1990), and the formation of $\mathrm{Fe}^{2+}$ via heterogeneous reaction of $\mathrm{SO}_{2}$ oxidation on the surface of $\mathrm{Fe}_{2} \mathrm{O}_{3}$ has already been verified by measuring the amount of $\mathrm{Fe}^{2+}$ during the reaction (Zhang et al., 2007; Ansari et al., 1997). Therefore, among the possible surface species in our reaction system, $\mathrm{Fe}^{2+}$ is the only reduced species that can react with $\mathrm{NO}_{3}^{-}$in the presence of $\mathrm{H}^{+}$. In other words, the only formation pathway of HONO is the reduction of $\mathrm{NO}_{3}^{-}$by the reductive $\mathrm{Fe}^{2+}$ in the presence of $\mathrm{H}^{+}$, while the reductant $\mathrm{Fe}^{2+}$ can be fed from the recycling from the reduction of $\mathrm{Fe}^{3+}$ by dissolved $\mathrm{SO}_{2}$. $\mathrm{HONO}$ formation processes in the atmosphere are still under discussion, especially during daytime where large discrepancies are found between mixing ratios calculated from known gasphase chemistry and measured daytime mixing ratios (Kleffmann et al., 2005). Our results also suggest that the heterogeneous reaction of $\mathrm{SO}_{2}$ on nitrate-containing hematite may serve as a potential source for HONO, which may have implications on the oxidant chemistry in the atmosphere. However, the low yield of gaseous HONO may suggest that the contribution of HONO by this pathway to the atmospheric gas-phase HONO may be negligible, but the formation of unreleased $\mathrm{HONO}$ in the particles may be significant for the conversion of $\mathrm{SO}_{2}$ and the formation of sulfate in the atmosphere.

In addition, it is interesting to note that $\mathrm{N}_{2} \mathrm{O}$ is formed in the process of the heterogeneous uptake of $\mathrm{SO}_{2}$ on the hematite-nitrate mixtures at both low and high $\mathrm{SO}_{2}$ concentrations. As shown in Fig. 5, two $\mathrm{N}_{2} \mathrm{O}$ absorption peaks at 2235 and $2208 \mathrm{~cm}^{-1}$ appear and slowly grow in intensity with the increase in reaction time (Hussain and Rahman, 2006), indicating that gas-phase $\mathrm{N}_{2} \mathrm{O}$ is produced in the FTIR experiments. The concentration of $\mathrm{N}_{2} \mathrm{O}$ gradually increases and approaches a constant (ca. $418 \mathrm{ppb}$ ) as the reaction proceeds (see Fig. 5f). The gas-phase concentrations of $\mathrm{N}_{2} \mathrm{O}$ are determined according to a linear relationship between the integrated area of the gaseous $\mathrm{N}_{2} \mathrm{O}$ absorption peaks in the range $2258-2160 \mathrm{~cm}^{-1}$ and its concentration $\left(r^{2}=0.996\right)$. The linear relationship is obtained using in situ White cellFTIR and different concentrations of $\mathrm{N}_{2} \mathrm{O}$ standard gas. The observed formation of $\mathrm{N}_{2} \mathrm{O}$ is of particular importance because it is an extremely influential greenhouse gas and directly involved in global warming as well as in the destruction of ozone in the stratosphere. It has been reported that $\mathrm{S}$ (IV) species such as $\mathrm{H}_{2} \mathrm{SO}_{3}$ can be easily oxidized by $\mathrm{HONO}$ at low $\mathrm{pH}(0.6-3.2)$ and the gas-phase product is $\mathrm{N}_{2} \mathrm{O}$ (Martin et al., 1981). Therefore, it is reasonable to speculate that $\mathrm{N}_{2} \mathrm{O}$ is formed from the reduction of HONO by $\mathrm{S}$ (IV) species such as sorbed or surface-coordinated $\mathrm{H}_{2} \mathrm{SO}_{3}$, $\mathrm{HSO}_{3}^{-}$, and $\mathrm{SO}_{3}^{2-}$ species on the mixture sample surface before HONO is released (Pires et al., 1996, 1997). This observation provides evidence for the formation of nitrous oxide from the hematite-nitrate mixtures at ambient temperature, and suggests a new potential atmospheric source of $\mathrm{N}_{2} \mathrm{O}$. 

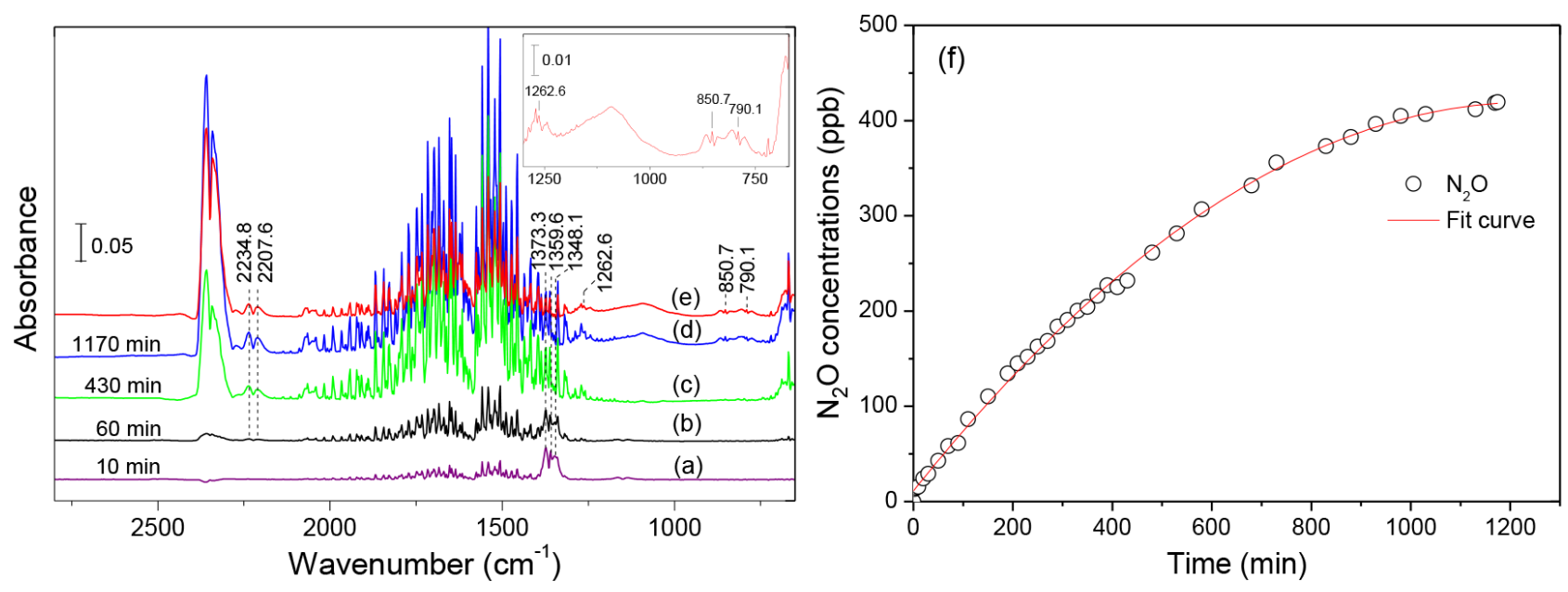

Figure 5. In situ FTIR spectra of FN-90 recorded upon exposure to $12.5 \mathrm{ppm} \mathrm{SO}+21 \% \mathrm{O}_{2}$ at room temperature for different times. Left panel: (a) $10 \mathrm{~min}$; (b) $60 \mathrm{~min}$; (c) $430 \mathrm{~min}$; (d) $1170 \mathrm{~min}$; and (e) difference spectrum: (d) minus (c). Right panel: (f) the concentration of the formed $\mathrm{N}_{2} \mathrm{O}$ as a function of time during the reaction of FN-90 sample with $\mathrm{SO}_{2}$.

This source is currently not accounted for in the global $\mathrm{N}_{2} \mathrm{O}$ budget. The result may help to explain why the sources of $\mathrm{N}_{2} \mathrm{O}$ exceed the estimated sinks in the atmosphere and the observed increase in atmospheric $\mathrm{N}_{2} \mathrm{O}$. However, it should be pointed out that the high surface-to-volume ratio of the experiments may lead to relatively more $\mathrm{N}_{2} \mathrm{O}$ than in the atmosphere. At the same time, the lifetime of HONO in the atmosphere is probably limited by photolysis. The relative importance of this source needs further study.

To further confirm the formation of $\mathrm{HONO}$ and $\mathrm{N}_{2} \mathrm{O}$, we also performed heterogeneous reactions of $\mathrm{SO}_{2}(50 \mathrm{ppm})$ on humid hematite, FN-24, and FN-90 in the presence of $\mathrm{O}_{2}$ $(21 \% v / v)$ in three brown glass bottles in the dark for 37 days. The dark condition is selected to avoid the photolysis of HONO and the photochemistry of adsorbed nitrate (Schuttlefield et al., 2008). The selected long reaction time favors the release of the produced HONO and the accumulation of $\mathrm{N}_{2} \mathrm{O}$. Figure 6 shows the digital photos of the three samples after reaction with $\mathrm{SO}_{2}$ in the dark at room temperature for about 7 days. Interestingly, the heterogeneous reactions of $\mathrm{SO}_{2}$ on the surfaces of FN-24 and FN-90 present unique phenomena, and some liquid drops cover the interior walls of glass bottles, which is different from that presented by the reaction of $\mathrm{SO}_{2}$ on the pure hematite. The latter does not show a similar phenomenon. The liquid drops show strong acidity, which has been measured with $\mathrm{pH}$ test paper (the $\mathrm{pH}$ was about 1). Ion chromatography analysis shows that the liquid drops mainly contain sulfate ions while the concentration of nitrate ions is below the detection limit. These results indicate that the liquid drop is sulfuric acid. The appearance of the liquid drops should be attributed to the presence of gas-phase HONO. Gas-phase HONO transforms $\mathrm{SO}_{2}$ that is present in the gas phase or adsorbed onto the bottle walls into sulfuric acid, while reactive HONO is produced from the het- erogeneous reaction of $\mathrm{SO}_{2}$ on the surface of the hematitenitrate mixture and the subsequent release. The HONO vapor adsorbs onto the interior wall of the glass bottle, and together with $\mathrm{H}_{2} \mathrm{O}$ initiates the oxidation of $\mathrm{SO}_{2}$ and the subsequent formation of $\mathrm{H}_{2} \mathrm{SO}_{4}$. Additionally, the gas-phase species in the three glass bottles were analyzed using the SPME/GCMS technique, and $\mathrm{N}_{2} \mathrm{O}$ is only found from the reactions of $\mathrm{SO}_{2}$ on $\mathrm{FN}-24$ and $\mathrm{FN}-90$, no $\mathrm{NO}, \mathrm{NO}_{2}$, and $\mathrm{N}_{2} \mathrm{O}_{4}$ are detected (see Fig. S6 in the Supplement). Therefore, considering the experimental results mentioned above, the formation of $\mathrm{HONO}$ and $\mathrm{N}_{2} \mathrm{O}$ during the reaction of $\mathrm{SO}_{2}$ on the hematite-nitrate mixture has been further verified by this experiment, which is consistent with the observations from in situ White Cell-FTIR experiments. This experiment also verifies that $\mathrm{N}_{2} \mathrm{O}$ and $\mathrm{HONO}$ can be produced from the reaction of $\mathrm{SO}_{2}$ on the hematite-sodium nitrate mixtures not only in daytime but also at night. Although the concentration of the formed HONO cannot be accurately measured during the process of the heterogeneous uptake of $\mathrm{SO}_{2}$ on the hematitenitrate mixture because the formed HONO is being continuously consumed on the particle surface, it may be important not only in daytime but also at night for the conversion of atmospheric $\mathrm{SO}_{2}$ and the formation of atmospheric sulfate. Such aspects should be further explored in future studies.

\subsection{Effect of nitrate on the morphology of surface prod- uct formed from the uptake of $\mathrm{SO}_{2}$ onto hematite}

Scanning electron micrographs of sample particles before and after reaction with gaseous $\mathrm{SO}_{2}$ were obtained from a Philips XL-30 scanning electron microscope equipped with an energy-dispersive X-ray spectrometer (SEM-EDX). Figure 7 shows SEM images of FN-24 and FN-90 particles before (Fig. 7a and c) and after (Fig. 7b and d) exposure to 


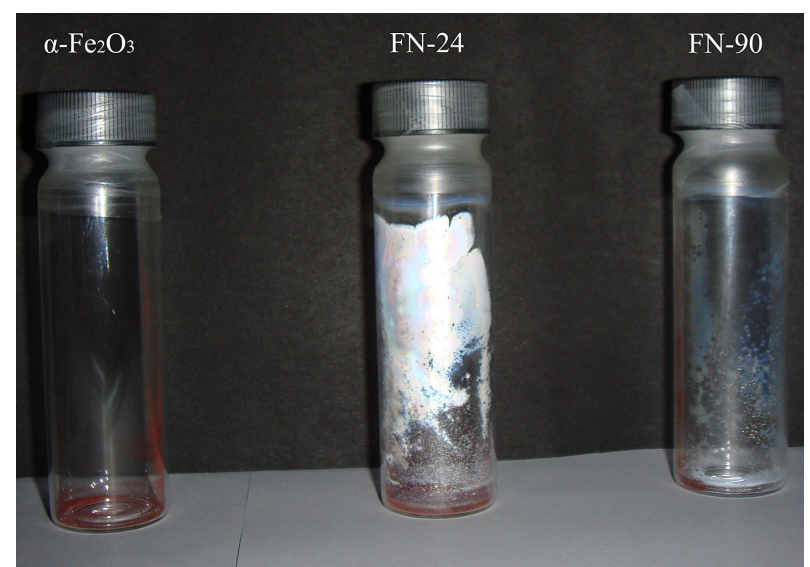

Figure 6. Digital photos of different samples after reaction with 50 ppm $\mathrm{SO}_{2}+21 \% \mathrm{O}_{2}$ in the dark at $298 \mathrm{~K}$ for about 7 days.

gaseous $\mathrm{SO}_{2}$ in the DRIFTS experiments. The two unreacted samples show the morphology of aggregated particles and consist of primary particles with an averaged particle size of over $100 \mathrm{~nm}$. After the reaction with $\mathrm{SO}_{2}$, there are some flaky substances covering some particle surfaces. EDX analysis shows that the flaky substance is composed of $57.89 \%$ $\mathrm{O}, 11.70 \% \mathrm{Na}, 11.48 \% \mathrm{~S}$, and $18.93 \% \mathrm{Fe}$ (Fig. 7e). The characteristic peaks in the EDX spectrum indicates that no nitrogen is detected on the flaky substance, indicating the formation of sulfate on the particle surface and the change in particle morphology. This result should be attributed to the enhanced formation of sulfate on the hematite surface due to the presence of nitrate. It should be noted that we cannot observe a similar phenomenon on the pure hematite after exposure to $\mathrm{SO}_{2}$.

\subsection{Role of surface adsorbed water under the influence of nitrate}

Previous studies indicate that surface-adsorbed water plays an important role in the heterogeneous chemistry of atmospheric $\mathrm{SO}_{2}$ (Nanayakkara et al., 2012). However, little is known about the role of surface-adsorbed water in the heterogeneous oxidation of $\mathrm{SO}_{2}$ on hematite-nitrate mixture. Therefore, the role of surface-adsorbed water in the heterogeneous oxidation of $\mathrm{SO}_{2}$ on $\mathrm{FN}-24$ was further investigated using in situ DRIFTS. In order to prevent the sample particles from being brought out from the in situ chamber, a vacuum was not applied during these experiments. The sample was first pretreated at preset temperature for $60 \mathrm{~min}$ in a stream of $\mathrm{Ar}$ in a total flow of $100 \mathrm{~mL} \mathrm{~min}^{-1}$. The preset temperatures were $298,303,373,423,473$, and $573 \mathrm{~K}$, respectively. After 60 min the heated sample in the reaction chamber was cooled to $298 \mathrm{~K}$ under Ar flow, and a background spectrum of the unreacted powder sample was collected. Subsequently, IR spectra were collected as a function of reaction time after being exposed to gaseous reactants. The results are shown

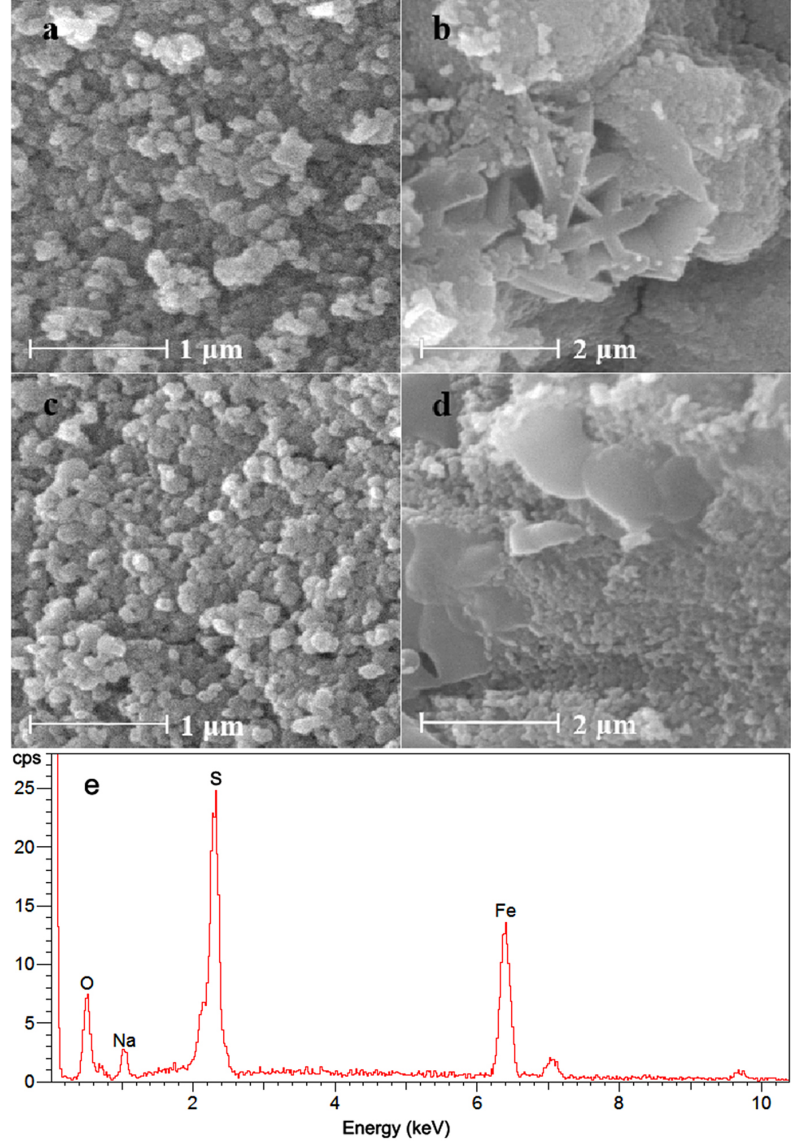

Figure 7. SEM images and EDX spectrum. Top panels: SEM images of FN-24 (a, b) and FN-90 (c, d) particles before (left) and after (right) exposure to $3 \mathrm{ppm} \mathrm{SO}_{2}$ at $298 \mathrm{~K}$ for $240 \mathrm{~min}$. Bottom panel: typical EDX spectrum of the flaky substance.

in Fig. 8. The pretreated sample at 373,423 , and $473 \mathrm{~K}$ enhances the reactivity of hematite, and the sulfate formation rates at 373 and $423 \mathrm{~K}$ increase by a factor of 1.28 and 1.25 compared with that at $298 \mathrm{~K}$, respectively, indicating that the presence of appropriate amount of water on particle surface will favor the heterogeneous conversion of $\mathrm{SO}_{2}$. However, with a further increase in pretreated temperature, the reactivity decreases, and the sample pretreated at $573 \mathrm{~K}$ shows even lower reactivity than that at $298 \mathrm{~K}$. Pretreatment of the sample is known to mainly remove surface-adsorbed water, and, at higher temperature, surface dehydration occurs. The observed increases in the reactivity of the sample pretreated at 373 and $423 \mathrm{~K}$ are due to the partial removal of physiadsorbed water, which may serve as an inhibitor for the $\mathrm{SO}_{2}$ oxidation by blocking access to the active sites. Samples pretreated at higher temperatures $(573 \mathrm{~K})$ display removal of the physiadsorbed water along with partial desorption of surface hydroxyl groups (Egashira et al., 1981), resulting in a decrease in the sample reactivity. In agreement with other 


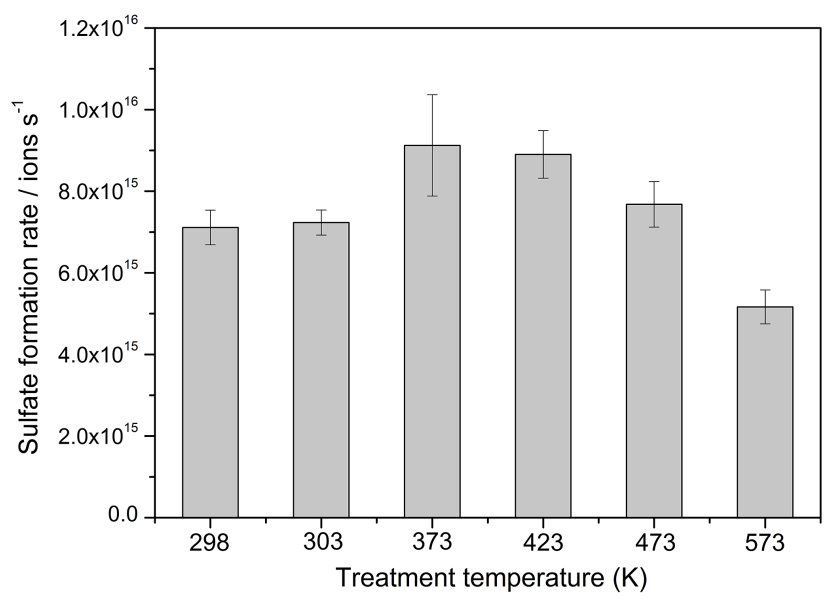

Figure 8. Sulfate formation rates on $30 \mathrm{mg}$ of $\mathrm{FN}-24$ after exposure to $3 \mathrm{ppm} \mathrm{SO}_{2}$ under different pretreatment temperatures.

studies, surface hydroxyl groups can be the active sites for the conversion of $\mathrm{SO}_{2}$.

\subsection{Proposed mechanism of $\mathrm{SO}_{2}$ uptake on hematite-nitrate mixtures}

On the basis of the experimental observations described above, a reaction mechanism for the heterogeneous reaction of $\mathrm{SO}_{2}$ on the hematite-nitrate mixture is proposed. Previous studies have shown that nitrate ions can be readily solvated by adsorbed water molecules under ambient conditions due to their hygroscopic nature (Hoffman et al., 2004), and thus nitrate in the mixture sample will cause more water molecules to be adsorbed on the particles when the prepared mixture sample is kept in a desiccator at $68 \% \mathrm{RH}$ for $48 \mathrm{~h}$, and leads to weak water loss during the purge and subsequent reaction processes. The adsorbed water will favor the uptake of $\mathrm{SO}_{2}$ and the formation of $\mathrm{S}$ (IV) species (Zhang et al., 2007; Preszler Prince et al., 2007). Therefore, in the initial stage of heterogeneous conversion of $\mathrm{SO}_{2}$ on the nitratehematite mixture, the following reactions will occur (Zhang et al., 2007):

$$
\begin{aligned}
& \mathrm{SO}_{2}+\mathrm{H}_{2} \mathrm{O} \rightarrow \mathrm{H}_{2} \mathrm{SO}_{3}, \\
& \mathrm{H}_{2} \mathrm{SO}_{3} \rightarrow \mathrm{H}^{+}+\mathrm{HSO}_{3}^{-} .
\end{aligned}
$$

Earlier studies of $\mathrm{SO}_{2}$ adsorption on metal oxides have shown that Lewis acid sites, hydroxyl groups, and oxygen vacancies can all play a role in the surface chemistry (Goodman et al., 2001; Fu et al., 2007; Baltrusaitis et al., 2007). Surface hydroxyl groups are involved in the adsorption of sulfur dioxide, and, in particular, sulfur dioxide reacts with either one surface $\mathrm{O}-\mathrm{H}$ group to yield adsorbed bisulfite or two surface $\mathrm{O}-\mathrm{H}$ groups to yield adsorbed sulfite and water. In the current study, the used nitrate-hematite mixtures are still loose, fine powders after they are saturated at $68 \% \mathrm{RH}$ for $48 \mathrm{~h}$, and there may be several water molecule layers residing on humid sample surfaces. Therefore, surface sulfate and/or bisulfate can also be produced on the nitrate-hematite mixture particles through surface active oxygen and hydroxyl, while the active oxygen and hydroxyl can be formed from the interaction of $\mathrm{O}_{2}$ and $\mathrm{H}_{2} \mathrm{O}$ with the surface of hematite (Baltrusaitis et al., 2007). The formation mechanism of the surface sulfate and/or bisulfate during initial reaction stages should also be the same as that reported previously (Goodman et al., 2001; Baltrusaitis et al., 2007; Fu et al., 2007; Zhang et al., 2007). That is, the gaseous $\mathrm{SO}_{2}$ reacts with surface active oxygen and hydroxyl to form surface $\mathrm{S}$ (IV) species (i.e., adsorbed sulfur species and surface-coordinated $\mathrm{HSO}_{3}^{-}$and $\mathrm{SO}_{3}^{2-}$ ), and then these $\mathrm{S}$ (IV) species are further oxidized to surface $\mathrm{S}(\mathrm{VI})$ species, including $\mathrm{SO}_{4}^{2-}$ and/or $\mathrm{HSO}_{4}^{-}$in the presence of $\mathrm{O}_{2}$ and $\mathrm{H}_{2} \mathrm{O}$ (Fu et al., 2007; Zhang et al., 2007; Preszler Prince et al., 2007).

The reactions mentioned above will lead to the formation of an acidic surface. On the acidic surface, hematite will be partially dissolved to give $\mathrm{Fe}^{3+}$ ions in the water-rich surface (Chun and Quon, 1973; Shi et al., 2011), which in turn oxidizes $\mathrm{HSO}_{3}^{-}$to form $\mathrm{SO}_{4}^{2-}$. As previously reported, $\mathrm{Fe}^{2+}$ ions are generated during this process (Behra and Sigg, 1990; Ansari et al., 1997; Zhang et al., 2007).

$6 \mathrm{H}^{+}+\mathrm{Fe}_{2} \mathrm{O}_{3} \rightarrow 2 \mathrm{Fe}^{3+}+3 \mathrm{H}_{2} \mathrm{O}$,
$2 \mathrm{Fe}^{3+}+\mathrm{HSO}_{3}^{-}+\mathrm{H}_{2} \mathrm{O} \rightarrow 2 \mathrm{Fe}^{2+}+\mathrm{SO}_{4}^{2-}+3 \mathrm{H}^{+}$.

It is well established that the nitrate ion is a strong oxidizing agent in highly acidic solutions that is capable of changing the oxidation state of reduced species (Burley and Johnston, 1992). As the above reactions proceed, the surface of the mixed hematite-nitrate sample becomes more acidic, and adsorbed nitric acid and nitric acid-water complexes are gradually formed on the surface. Once the surface becomes sufficiently acidified, the interaction between nitric acid and $\mathrm{Fe}^{2+}$ ion occurs on acidic surface, and the $\mathrm{Fe}^{2+}$ ion is oxidized and HONO is produced (Summers, 2005), as given in the following ionic equation:

$2 \mathrm{Fe}^{2+}+3 \mathrm{H}^{+}+\mathrm{NO}_{3}^{-} \rightarrow 2 \mathrm{Fe}^{3+}+\mathrm{HONO}+\mathrm{H}_{2} \mathrm{O}$.

The re-generated $\mathrm{Fe}^{3+}$ further oxidizes the $\mathrm{S}$ (IV) species to $\mathrm{S}(\mathrm{VI})$ species and produces $\mathrm{Fe}^{2+}$ ions. With the cycle of the above reactions, more and more sulfates and HONO are produced. As shown in previous studies, S (IV) species can be rapidly oxidized to sulfate by HONO, and HONO can be reduced to $\mathrm{N}_{2} \mathrm{O}$ in acidic aqueous aerosols (Martin et al., 1981; Pires et al., 1996, 1997). Thus, the formed HONO is also considered to react promptly with surface $\mathrm{S}$ (IV) species (i.e., sorbed $\mathrm{H}_{2} \mathrm{SO}_{3}, \mathrm{HSO}_{3}^{-}$and $\mathrm{SO}_{3}^{2-}$ ) before it escapes to the gas phase, which also results in the formation of $\mathrm{N}_{2} \mathrm{O}$ and more sulfates on the particle surface. As reported previously 
(Martin et al., 1981), the stoichiometry should be as follows:

$$
\begin{aligned}
& 2 \mathrm{HONO}+2 \mathrm{H}_{2} \mathrm{SO}_{3} \rightarrow 2 \mathrm{H}_{2} \mathrm{SO}_{4}+\mathrm{N}_{2} \mathrm{O}+\mathrm{H}_{2} \mathrm{O}, \\
& 2 \mathrm{HONO}+2 \mathrm{HSO}_{3}^{-} \rightarrow 2 \mathrm{SO}_{4}^{2-}+\mathrm{N}_{2} \mathrm{O}+\mathrm{H}_{2} \mathrm{O}+2 \mathrm{H}^{+}, \\
& 2 \mathrm{HONO}+2 \mathrm{SO}_{3}^{2-} \rightarrow 2 \mathrm{SO}_{4}^{2-}+\mathrm{N}_{2} \mathrm{O}+\mathrm{H}_{2} \mathrm{O} .
\end{aligned}
$$

An alternate mechanism involving consumption of $\mathrm{HONO}$ and formation of sulfate is based on that proposed by Finlayson-Pitts et al. (2003) and Liu et al. (2012). That is, reaction of the surface formed $\mathrm{HONO}$ with $\mathrm{HNO}_{3}$ on the surface generates $\mathrm{NO}^{+} \mathrm{NO}_{3}^{-}$. This reaction can be thought of as a reaction of $\mathrm{NO}_{3}^{-}$with $\mathrm{NO}^{+}$formed from the reaction of $\mathrm{HONO}$ with the $\mathrm{HNO}_{3}$, i.e., the reverse of the overall $\mathrm{NO}_{2}$ hydrolysis reaction. The reaction process may be as follows:

$\mathrm{HONO}_{\text {(surface) }}+\mathrm{HNO}_{3 \text { (surface) }} \rightarrow \mathrm{NO}^{+} \mathrm{NO}_{3}^{-}$(surface) $+\mathrm{H}_{2} \mathrm{O}$.

Some $\mathrm{NO}^{+} \mathrm{NO}_{3}^{-}$(surface) isomerizes to surface asymmetric $\mathrm{ONONO}_{2}$, and then $\mathrm{ONONO}$ converts to a small amount of $\mathrm{N}_{2} \mathrm{O}_{4}$ (Finlayson-Pitts et al., 2003; Liu et al., 2012). The formed $\mathrm{N}_{2} \mathrm{O}_{4}$ interacts strongly with water and adsorbed $\mathrm{HNO}_{3}$ and would be more likely present on the surface (Finlayson-Pitts et al., 2003). Some $\mathrm{NO}^{+} \mathrm{NO}_{3}^{-}$(surface) oxidizes surface $\mathrm{S}(\mathrm{IV})$ species to sulfate, while $\mathrm{NO}^{+} \mathrm{NO}_{3}^{-}$itself is reduced to nitrite ( $\mathrm{M}$ represents the surface metal sites). This can explain small amounts of $\mathrm{N}_{2} \mathrm{O}_{4}$ and nitrite observed in our study:

$$
\begin{aligned}
& \mathrm{NO}^{+} \mathrm{NO}_{3}^{-} \text {(surface) } \rightarrow \mathrm{ONONO}_{2 \text { (surface) }} \rightarrow \mathrm{N}_{2} \mathrm{O}_{4 \text { (surface) }} \text {, } \\
& \mathrm{NO}^{+} \mathrm{NO}_{3 \text { (surface) }}^{-}+\mathrm{MSO}_{3} \rightarrow \mathrm{MSO}_{4}+\mathrm{NO}^{+} \mathrm{NO}_{2}^{-} \text {. }
\end{aligned}
$$

Once the surface $\mathrm{S}$ (IV) species have been completely consumed, the remaining $\mathrm{NO}^{+} \mathrm{NO}_{3}^{-}$will react with surface adsorbed water to generate $\mathrm{HONO}$ and adsorbed $\mathrm{HNO}_{3}$ (Finlayson-Pitts et al., 2003), and subsequently the formed HONO through the reaction of $\mathrm{NO}^{+} \mathrm{NO}_{3}^{-}$with water and the unconsumed HONO by S (IV) species will be slowly released into the gas phase. Accordingly, $\mathrm{HONO}$ rather than $\mathrm{N}_{2} \mathrm{O}_{4}$ is responsible for the formation of $\mathrm{H}_{2} \mathrm{SO}_{4}$ liquid drops on the interior wall of the glass bottle in the dark.

$$
\begin{aligned}
& \mathrm{NO}^{+} \mathrm{NO}_{3}^{-}(\text {surface) } \\
& \rightarrow \mathrm{H}_{2} \mathrm{O}_{(\text {surface })} \\
& \rightarrow \mathrm{HONO}_{(\mathrm{g} \text {, surface })}+\mathrm{HNO}_{3 \text { (surface) }}
\end{aligned}
$$

Therefore, the appearance of HONO will favor the oxidation of S (IV) species on the surface and lead to the formation of more sulfates (Martin et al., 1981). With the cycle of the above reactions, more and more sulfates and $\mathrm{N}_{2} \mathrm{O}$ are produced. Once the reduced S (IV) species on the surface have been completely consumed, the remaining and subsequently formed HONO will slowly escape into the gas phase and be detected by FTIR.

In addition, it is well known that $\mathrm{N}_{2} \mathrm{O}$ can be formed during heterogeneous hydrolysis of gas-phase $\mathrm{NO}_{2}$ via $\mathrm{HONO}$

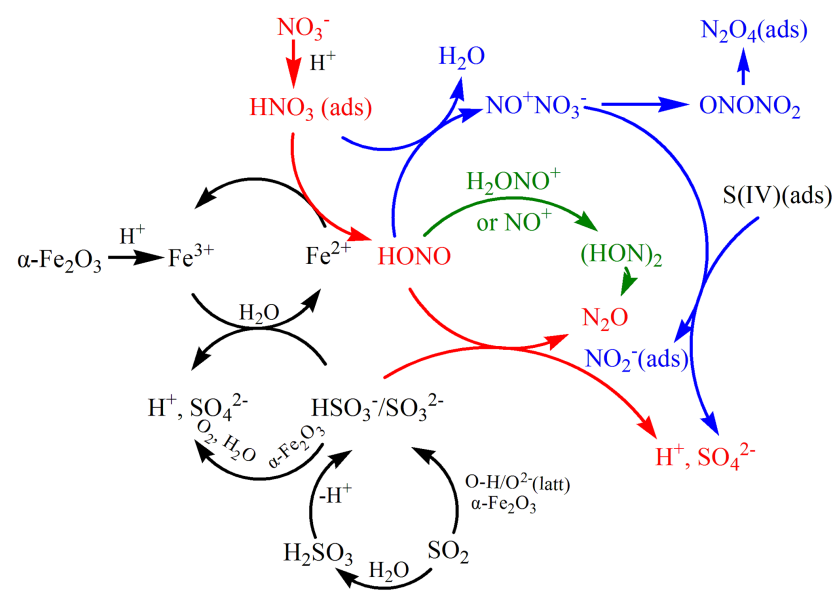

Figure 9. Schematic of the reaction mechanism of the heterogeneous oxidation of $\mathrm{SO}_{2}$ on hematite in the presence of nitrate.

on acidic oxide surfaces (Finlayson-Pitts et al., 2003; Wiesen et al., 1995). Therefore, another possibility for the formation of $\mathrm{N}_{2} \mathrm{O}$ is similar to the conversion proposed by FinlaysonPitts et al. (2003) and Wiesen et al. (1995). That is, reaction of $\mathrm{HONO}$ and its protonated forms $\left(\mathrm{H}_{2} \mathrm{ONO}^{+}\right.$or possibly $\mathrm{NO}^{+}$) generates hyponitrous acid, $\mathrm{HON}=\mathrm{NOH}$. The selfreaction of $(\mathrm{HON})_{2}$ then decomposes to $\mathrm{N}_{2} \mathrm{O}$ under acidic conditions. Similar chemistry has also been proposed for the formation of $\mathrm{N}_{2} \mathrm{O}$ under acidic conditions in the presence of $\mathrm{SO}_{2}$ (Pires et al., 1997).

Above all, the consumed nitrate during the reaction will favor the uptake of more $\mathrm{SO}_{2}$ molecules and produce more surface sulfate, while secondary chemistry of intermediate HONO will also result in the formation of gas-phase $\mathrm{N}_{2} \mathrm{O}$. Furthermore, more adsorbed or surface-coordinated S (IV) species produced from higher concentrations of $\mathrm{SO}_{2}$ also indicate that it will take a longer reaction time to observe the formation of gaseous HONO. The proposed mechanism provides new insights into some unsolved atmospheric problems such as unknown sources of $\mathrm{N}_{2} \mathrm{O}$ and potential HONO, unknown $\mathrm{SO}_{2}$ sinks, and unknown sulfate formation pathways in the troposphere, and this chemistry also helps to explain the discrepancy between model-predicted sulfate and field observations of sulfate in the atmosphere (Laskin et al., 2003). The reaction mechanism of the heterogeneous oxidation of $\mathrm{SO}_{2}$ on hematite in the presence of nitrate is summarized in Fig. 9.

\section{Conclusions}

The effects of nitrate on heterogeneous conversion of $\mathrm{SO}_{2}$ on hematite at room temperature have been investigated. It is found that nitrate participates in the heterogeneous reactions of $\mathrm{SO}_{2}$, changes the conversion pathway of $\mathrm{SO}_{2}$, and leads to the formation of $\mathrm{HNO}_{3}, \mathrm{~N}_{2} \mathrm{O}, \mathrm{HONO}$, and more sulfate, revealing that nitrate has a significant impact on the 
heterogeneous conversion of $\mathrm{SO}_{2}$ to sulfate. The heterogeneous uptake of $\mathrm{SO}_{2}$ on hematite is enhanced by a low to moderate amount of nitrate, and more sulfates are formed on hematite. For mixtures, the sample containing $24 \%$ nitrate exhibits the highest sulfate formation rate, and its corresponding uptake coefficient calculated by geometric surface area is about 5.5 times higher than that of hematite alone. The sample containing $48 \%$ nitrate presents the highest BET uptake coefficient, and the value is about 8 times higher than that of pure hematite. The enhanced formation of sulfate on particle surfaces and the change of particle surfaces would affect the hygroscopicity, optical properties, and lifetime of the particle in the atmosphere. The observed formation of $\mathrm{HONO}$ and $\mathrm{N}_{2} \mathrm{O}$ is of particular importance. The formation of potential HONO by this pathway may be significant for the conversion of $\mathrm{SO}_{2}$ and the formation of sulfate in the atmosphere. The observed formation of $\mathrm{N}_{2} \mathrm{O}$ may help to explain the difference between the sources of $\mathrm{N}_{2} \mathrm{O}$ and the estimated sinks in the atmosphere and the observed increase in atmospheric $\mathrm{N}_{2} \mathrm{O}$. This study not only reveals the effects of nitrate on heterogeneous conversion of $\mathrm{SO}_{2}$ on hematite but also provides new pathways for the formation of secondary sulfate aerosols, $\mathrm{N}_{2} \mathrm{O}$, and potential $\mathrm{HONO}$.

Results from this study have important atmospheric implications. Firstly, the results suggest that the heterogeneous conversion of $\mathrm{SO}_{2}$ in the atmosphere will be affected by the availability of nitrate, and they further emphasize the complexity of the reaction of $\mathrm{SO}_{2}$ on mineral dust. This chemistry may occur on surfaces of airborne dust particles that are known to be transported and play a role in the chemistry of the troposphere, which would affect the estimation of the amount of global atmospheric sulfate, and further affect the previously estimated radiative forcing and cooling effect of sulfate aerosols in the atmosphere (Dentener et al., 1996). Secondly, Fe (II) in airborne particles has been observed (Zhu et al., 1997; Zhuang et al., 2001) and its concentration in dust increased continuously during long-range transport (Zhuang et al., 2001). Also, in the real atmospheric systems, sulfuric acid is a common component of particles (FinlaysonPitts and Pitts, 2000). $\mathrm{PM}_{2.5}$ is generally acidic due to partial neutralization of acidic sulfate and nitrate under some atmospheric conditions (Huang et al., 2011), and even dust particles might become acidified to $\mathrm{pH}<2$ in the troposphere (Meskhidze et al., 2003). The Fe (II)-containing airborne particles will inevitably be loaded by nitrate and be acidified through contact with acidic particles, such as sulfuric acid aerosols and acidic $\mathrm{PM}_{2.5}$ particles, or become the heterogeneous reaction interface of $\mathrm{SO}_{2}$ and $\mathrm{NO}_{2}$ in the atmosphere. Hence, we can expect the production of potential HONO during these processes. The results presented here may imply that such a heterogeneous conversion pathway of low concentration $\mathrm{SO}_{2}$ on nitrate-containing airborne dust particles may be a potential and yet unknown daytime and nighttime significant source of HONO, and they reveal that the presence of nitrate on mineral dust aerosol may play a role in the chemistry of HONO in the troposphere. In the meantime, these particles containing potential HONO may become the oxidizing carriers for the oxidation of atmospheric reduced gases, thereby enhancing the atmospheric oxidation ability. Understanding this chemistry will contribute to the elucidation of the potential contribution of the unreleased HONO in the particle for the conversion of $\mathrm{SO}_{2}$ and the enhanced formation of sulfate in the atmosphere in the daytime and at night. Finally, several studies have indicated that the photolysis of aqueous nitrate (Dubowski et al., 2001; Roca et al., 2008) and adsorbed nitrate (Schuttlefield et al., 2008) is a source of $\mathrm{NO}_{x}$ (i.e., $\left.\mathrm{NO}+\mathrm{NO}_{2}\right), \mathrm{OH}$ radicals, and $\mathrm{O}\left({ }^{3} \mathrm{P}\right)$. All of these products represent highly reactive oxidants in the gas phase and in other environmentally relevant phases. The production of hydroxyl radicals will favor the conversion of $\mathrm{SO}_{2}$ to particulate sulfate, while the photolysis of aqueous or adsorbed nitrate will lead to a loss of nitrate in the particulate phase. Furthermore, according to our experimental results and discussion above, low to moderate amounts of nitrate will significantly promote the heterogeneous conversion of $\mathrm{SO}_{2}$ and the formation of sulfate on airborne hematitecontaining mineral dust particles, while the heterogeneous uptake of $\mathrm{SO}_{2}$ on nitrate-containing mineral dust in the atmosphere will also bring a loss of adsorbed nitrate on the particle surface with the concomitant formation of gas-phase products, including $\mathrm{HONO}$ and $\mathrm{N}_{2} \mathrm{O}$. Therefore, these studies mentioned above will aid in understanding the negative linear correlation between sulfate and nitrate contents in ambient particles (Kong et al., 2014). However, the reasons for the negative correlation are unknown. There is still lack of corresponding research on the formation mechanism of the negative correlation up to now, and all of these aspects need to be further investigated.

\section{The Supplement related to this article is available online at doi:10.5194/acp-14-9451-2014-supplement.}

Acknowledgements. This work was supported by the National Natural Science Foundation of China (grant nos. 21277028, 40775079, 21190053, and 41275126) and the Scientific Research Foundation for the Returned Overseas Chinese Scholars, State Education Ministry.

Edited by: B. Ervens

\section{References}

Ansari, A., Peral, J., Domènech, X., and Rodriquez-Clemente, R.: Oxidation of $\mathrm{HSO}_{3}^{-}$in aqueous suspensions of $\alpha-\mathrm{Fe}_{2} \mathrm{O}_{3}, \alpha$ $\mathrm{FeOOH}, \beta-\mathrm{FeOOH}$ and $\gamma-\mathrm{FeOOH}$ in the dark and under illumination, Environ. Pollut., 95, 283-288, 1997. 
Arens, F., Gutzwiller, L., Baltensperger, U., Gäggler, H. W., and Ammann, M.: Heterogeneous reaction of $\mathrm{NO}_{2}$ on diesel soot particles, Environ. Sci. Technol., 35, 2191-2199, 2001.

Baltrusaitis, J., Cwiertny, D. M., and Grassian, V. H.: Adsorption of sulfur dioxide on hematite and goethite particle surfaces, Phys. Chem. Chem. Phys., 9, 5542-5554, 2007.

Behra, P. and Sigg, L.: Evidence for redox cycling of iron in atmospheric water droplets, Nature, 344, 419-421, 1990.

Börensen, C., Kirchner, U., Scheer, V., Vogt, R., and Zellner R.: Mechanism and kinetics of the reactions of $\mathrm{NO}_{2}$ or $\mathrm{HNO}_{3}$ with alumina as a mineral dust model compound, J. Phys. Chem. A, 104, 5036-5045, 2000.

Burley, J. D. and Johnston, H. S.: Ionic mechanisms for heterogeneous stratospheric reactions and ultraviolet photoabsorption cross sections for $\mathrm{NO}_{2}^{+}, \mathrm{HNO}_{3}$, and $\mathrm{NO}_{3}^{-}$in sulfuric acid, Geophys. Res. Lett., 19, 1359-1361. 1992.

Chun, K. C. and Quon, J. E.: Capacity of ferric oxide particles to oxidize sulfur dioxide in air, Environ. Sci. Technol., 7, 532-538, 1973.

Dentener, F. J., Carmichael, G. R., Zhang, Y., Lelieveld, J., and Crutzen, P. J.: Role of mineral aerosol as a reactive surface in the global troposphere, J. Geophys Res., 101, 22869-22889, 1996.

Drescher, S. R. and Brown, S. D.: Solid phase microextractiongas chromatographic-mass spectrometric determination of nitrous oxide evolution to measure denitrification in estuarine soils and sediments, J. Chromatogr. A, 1133, 300-304, 2006.

Dubowski, Y., Colussi, A. J., and Hoffmann, M. R.: Nitrogen dioxide release in the $302 \mathrm{~nm}$ band photolysis of spray-frozen aqueous nitrate solutions, Atmospheric implications, J. Phys. Chem. A, 105, 4928-4932, 2001.

Egashira, M., Nakashima, M., Kawasumi, S., and Seiyama, T.: Temperature programmed desorption study of water adsorbed on metal oxides. 2. Tin oxide surfaces, J. Phys. Chem., 85, 41254130, 1981.

Faguy, P. W. and Marinković, N. S.: An in situ infrared study on the effect of $\mathrm{pH}$ on anion adsorption at $\mathrm{Pt}$ (111) electrodes from acid sulfate solutions, Langmuir, 12, 243-247, 1996.

Finlayson-Pitts, B. J. and Pitts, J. N.: Chemistry of the upper and lower atmosphere: Theory, experiments, and applications, Academic Press, San Diego, CA, 2000.

Finlayson-Pitts, B. J., Wingen, L. M., Sumner, A. L., Syomin, D., and Ramazan, K. A.: The heterogeneous hydrolysis of $\mathrm{NO}_{2}$ in laboratory systems and in outdoor and indoor atmospheres: An integrated mechanism, Phys. Chem. Chem. Phys., 5, 223-242, 2003.

Fu, H., Wang, X., Wu, H., Yin, Y., and Chen, J.: Heterogeneous uptake and oxidation of $\mathrm{SO}_{2}$ on iron oxides, J. Phys. Chem. C, 111, 6077-6085, 2007.

Goodman, A. L., Underwood, G. M., and Grassian, V. H.: A spectroscopic investigation of the heterogeneous reaction $2 \mathrm{NO}_{2}+$ $\mathrm{H}_{2} \mathrm{O}$ (a) $\rightarrow \mathrm{HONO}(\mathrm{g})+\mathrm{HNO}_{3}$ (a) on hydrated silica Particles: Characterization of gas-phase and adsorbed products, J. Phys. Chem. A, 103, 7217-7223, 1999.

Goodman, A. L., Li, P., Usher, C. R., and Grassian, V. H.: Heterogeneous uptake of sulfur dioxide on aluminum and magnesium oxide particles, J. Phys. Chem. A, 105, 6109-6120, 2001.

Harris, E., Sinha, B., van Pinxteren, D., Tilgner, A., Fomba, K. W., Schneider, J., Roth, A., Gnauk, T., Fahlbusch, B., Mertes, S., Lee, T., Collett, J., Foley, S., Borrmann, S., Hoppe, P., and Her- rmann, H.: Enhanced role of transition metal ion catalysis during in-cloud oxidation of $\mathrm{SO}_{2}$, Science, 340, 727-730, 2013.

Hixson, B. C., Jordan, J. W., Wagner, E. L., and Holly M.: Reaction products and kinetics of the reaction of $\mathrm{NO}_{2}$ with $\gamma-\mathrm{Fe}_{2} \mathrm{O}_{3}, \mathrm{~J}$. Phys. Chem. A, 115, 13364-13369, 2011.

Ho, K. F., Lee, S. C., Chan, C. K., Yu, J. C., Chow, J. C., and Yao, X. H.: Characterization of chemical species in $\mathrm{PM}_{2.5}$ and $\mathrm{PM}_{10}$ aerosols in Hong Kong, Atmos. Environ., 37, 31-39, 2003.

Hoffman, R. C., Laskin, A., and Finlayson-Pitts, B. J.: Sodium nitrate particles: physical and chemical properties during hydration and dehydration, and implications for aged sea salt aerosols, J. Aerosol Sci., 35, 869-887, 2004.

Huang, X., Qiu, R., Chan, C. K., and Kant, P. R.: Evidence of high $\mathrm{PM}_{2.5}$ strong acidity in ammonia-rich atmosphere of Guangzhou, China: Transition in pathways of ambient ammonia to form aerosol ammonium at $\left[\mathrm{NH}_{4}^{+}\right] /\left[\mathrm{SO}_{4}^{2-}\right]=1.5$, Atmos. Res., 99, 488-495, 2011.

Hug, S. J.: In situ Fourier transform infrared measurements of sulfate adsorption on hematite in aqueous solutions, J. Colloid Interf. Sci., 188, 415-422, 1997.

Hussain, G. and Rahman, M. M.: An infrared study of co-adsorption of $\mathrm{N}_{2} \mathrm{O}$ and $\mathrm{CO}$ on $\mathrm{ZnO}$, Spectrochim. Acta, 64, 880-885, 2006.

Jickells, T. D. and Spokes, L. J.: Atmospheric iron inputs to the ocean, in: the biogeochemistry of iron in seawater, edited by: Turner, D. R. and Hunter, K. A., SCOR-IUPAC Series, J. Wiley, Baltimore, 85-121, 2001.

Kasibhatla, P., Chameides, W. L., and St John, J.: A threedimensional global model investigation of seasonal variations in the atmospheric burden of anthropogenic sulfate aerosols, J. Geophys. Res., 102, 3737-3759, 1997.

Kerminen, V., Pirjola, L., Boy, M., Eskola, A., Teinilä, K., Laakso, L., Asmi, A., Hienola, J., Lauri, A., Vainio, V., Lehtinen, K., and Kulmala, M.: Interaction between $\mathrm{SO}_{2}$ and submicron atmospheric particles, Atmos. Res., 54, 41-57, 2000.

Kleffmann, J., Gavriloaiei, T., Hofzumahaus, A., Holland, F., Koppmann, R., Rupp, L., Schlosser, E., Siese, M., and Wahner, A.: Daytime formation of nitrous acid: A major source of $\mathrm{OH}$ radicals in a forest, Geophys. Res. Lett., 32, L05818, doi:10.1029/2005GL022524, 2005.

Koch, T. G., Horn, A. B., Chesters, M. A., McCoustra, M. R. S., and Sodeau, J. R.: A low-temperature reflection-absorption infrared spectroscopic study of ultrathin films of dinitrogen tetroxide and dinitrogen pentoxide on gold foil, J. Phys. Chem., 99, 8362-8367, 1995.

Kong, L., Yang, Y., Zhang, S., Zhao, X., Du, H., Fu, H., Zhang, S., Cheng, T., Yang, X., Chen, J., Wu, D., Shen, J., Hong, S., and Jiao, L.: Observations of linear dependence between sulfate and nitrate in atmospheric particles, J. Geophys. Res., 119, 341-361, 2014.

Laskin, A., Gaspar, D. J., Wang, W. H., Hunt, S. W., Cowin, J. P., Colson, S. D., and Finlayson-Pitts, B. J.: Reactions at interfaces as a source of sulfate formation in sea-salt particles, Science, 301, 340-344, 2003.

Lin, L., Kong, L., and Chen, J.: Experimental study of the effects of ammonium nitrate on $\mathrm{SO}_{2}$ gas-particle transfer on the surface of atmospheric aerosols, Chem. J. Chinese U., 31, 751-755, 2010.

Liu, C., Ma, Q., Liu, Y., Ma, J., and He, H.: Synergistic reaction between $\mathrm{SO}_{2}$ and $\mathrm{NO}_{2}$ on mineral oxides: A potential formation 
pathway of sulfate aerosol, Phys. Chem. Chem. Phys., 14, 16681676, 2012.

Luria, M. and Sievering, H.: Heterogeneous and homogeneous oxidation of $\mathrm{SO}_{2}$ in the remote marine atmosphere, Atmos. Environ., 25, 1489-1496, 1991.

Martin, L. R., Damschen, D. E., and Judeikis, H. S.: The reactions of nitrogen oxides with $\mathrm{SO}_{2}$ in aqueous aerosols, Atmos. Environ., 15, 191-195, 1981.

McCurdy, P. R., Hess, W. P., and Sotiris, S.: Nitric Acid-Water Complexes: Theoretical Calculations and Comparison to Experiment, J. Phys. Chem. A, 106, 7628-7635, 2002.

Meskhidze, N., Chameides, W. L., Nenes, A., and Chen, G.: Iron mobilization in mineral dust: Cananthropogenic $\mathrm{SO}_{2}$ emissions affect ocean productivity?, Geophys. Res. Lett., 30, 2085-2089, 2003.

Moore, J. K., Doney, S. C., Glover, D. M., and Fung, I. Y.: Iron cycling and nutrient-limitation patterns in surface waters of the World Ocean, Deep-Sea Res. Pt. II, 49, 463-507, 2002.

Nanayakkara, C. E., Pettibone, J., and Grassian, V. H.: Sulfur dioxide adsorption and photooxidation on isotopically-labeled titanium dioxide nanoparticle surfaces: Roles of surface hydroxyl groups and adsorbed water in the formation and stability of adsorbed sulfite and sulfate, Phys. Chem. Chem. Phys., 14, 69576966, 2012.

Peak, D., Ford, R. G., and Sparks, D.: An in situ ATR-FTIR investigation of sulfate bonding mechanisms on goethite, J. Colloid Interf. Sci., 218, 289-299, 1999.

Persson, P. and Lovgren, L.: Potentiometric and spectroscopic studies of sulfate complexation at the goethite-water interface, Geochim. Cosmochim. Ac., 60, 2789-2799, 1996.

Pires, M., Van Den Bergh, H., and Rossi, M. J.: The heterogeneous formation of $\mathrm{N}_{2} \mathrm{O}$ over bulk condensed phases in the presence of $\mathrm{SO}_{2}$ at high humidities, J. Atmos. Chem., 25, 229-250, 1996.

Pires, M., Van Den Bergh, H., and Rossi, M. J.: The heterogeneous formation of $\mathrm{N}_{2} \mathrm{O}$ in the presence of acidic solutions: Experiments and modeling, Int. J. Chem. Kinet., 29, 869-891, 1997.

Pitts Jr., J. N., Sanhueza, E., Atkinson, R., Carter, W. P. L., Winer, A. M., Harris, G. W., and Plum, C. N.: An investigation of the dark formation of nitrous acid in environmental chambers, Int. J. Chem. Kinet., 16, 919-939, 1984.

Preszler Prince, A., Kleiber, P. D., Grassian, V. H., and Young, M. A.: Heterogeneous interactions of calcite aerosol with sulfur dioxide and sulfur dioxide/nitric acid mixtures, Phys. Chem. Chem. Phys., 9, 3432-3439, 2007.

Ramazan, K. A., Wingen, L. M., Miller, Y., Chaban, G. M., Gerber, R. B., Xantheas, S. S., and Finlayson-Pitts, B. J.: New experimental and theoretical approach to the heterogeneous hydrolysis of $\mathrm{NO}_{2}$ : Key role of molecular nitric acid and its complexes, J. Phys. Chem. A, 110, 6886-6897, 2006.

Rivera-Figueroa, A. M., Sumner, A. L., and Finlayson-Pitts, B. J.: Laboratory studies of potential mechanisms of renoxification of tropospheric nitric acid, Environ. Sci. Technol., 37, 548-554, 2003.

Roca, M., Zahardis, J., Bone, J., El-Maazawi, M., and Grassian, V. H.: $310 \mathrm{~nm}$ irradiation of atmospherically relevant concentrated aqueous nitrate solutions: Nitrite production and quantum yields, J. Phys. Chem. A, 112, 13275-13281, 2008.
Schuttlefield, J., Rubasinghege, G., El-Maazawi, M., Bone, J., and Grassian, V. H.: Photochemistry of adsorbed nitrate, J. Am. Chem. Soc., 130, 12210-12211, 2008.

Schwertmann, U. and Cornell, R. M.: Iron oxides in the laboratory: Preparation and characterization, Wiley-VCH, New York, 126$128,2000$.

Seinfeld, J. H. and Pandis, S. N.: Atmospheric Chemistry and Physics: From Air Pollution to Climate Change, 2nd Edn., John Wiley \& Sons Inc., New York, 2006.

Shi, Z., Bonneville, S., Krom, M. D., Carslaw, K. S., Jickells, T. D., Baker, A. R., and Benning, L. G.: Iron dissolution kinetics of mineral dust at low $\mathrm{pH}$ during simulated atmospheric processing, Atmos. Chem. Phys., 11, 995-1007, doi:10.5194/acp11-995-2011, 2011.

Sugimoto, T. and Wang, Y.: Mechanism of the shape and structure control of monodispersed $\alpha-\mathrm{Fe}_{2} \mathrm{O}_{3}$ particles by sulfate ions, J. colloid Interf. Sci., 207, 137-149, 1998.

Summers, D. P.: Ammonia formation by the reduction of nitrite/nitrate by FeS: Ammonia formation under acidic conditions, Origins Life Evol. B., 35, 299-312, 2005.

Ullerstam, M., Vogt, R., Langer, S., and Ljungström, E.: The kinetics and mechanism of $\mathrm{SO}_{2}$ oxidation by $\mathrm{O}_{3}$ on mineral dust, Phys. Chem. Chem. Phys., 4, 4694-4699, 2002.

Ullerstam, M., Johnson, M. S., Vogt, R., and Ljungström, E.: DRIFTS and Knudsen cell study of the heterogeneous reactivity of $\mathrm{SO}_{2}$ and $\mathrm{NO}_{2}$ on mineral dust, Atmos. Chem. Phys., 3, 2043-2051, doi:10.5194/acp-3-2043-2003, 2003.

Underwood, G. M., Miller, T. M., and Grassian, V. H.: Transmission FT-IR and Knudsen cell study of the heterogeneous reactivity of gaseous nitrogen dioxide on mineral oxide particles, J. Phys. Chem. A, 103, 6184-6190, 1999.

Usher, C. R., Al-Hosney, H., Carlos-Cuellar, S., and Grassian, V. H.: A laboratory study of the heterogeneous uptake and oxidation of sulfur dioxide on mineral dust particles, J. Geophys. Res., 107, 4713-4721, 2002.

Usher, C. R., Michel, A. E., and Grassian, V. H.: Reactions on mineral dust, Chem. Rev., 103, 4883-4939, 2003.

Watanabe, H., Gutleben, C. D., and Seto, J.: Sulfate ions on the surface of maghemite and hematite, Solid State Ionics, 69, 2935, 1994.

Wiesen, P., Kleffmann, J., Kurtenbach, R., and Becker, K. H.: Mechanistic study of the heterogeneous conversion of $\mathrm{NO}_{2}$ into $\mathrm{HONO}$ and $\mathrm{N}_{2} \mathrm{O}$ on acid surfaces, Faraday Discuss., 100, 121127, 1995.

Wingen, L. M., Barney, W. S., Lakin, M. J., Brauers, T., and Finlayson-Pitts, B. J.: A unique method for laboratory quantification of gaseous nitrous acid (HONO) using the reaction $\mathrm{HONO}$ $+\mathrm{HCl} \rightarrow \mathrm{ClNO}+\mathrm{H}_{2}$ O, J. Phys. Chem. A, 104, 329-335, 2000.

Wu, L. Y., Tong, S. R., Wang, W. G., and Ge, M. F.: Effects of temperature on the heterogeneous oxidation of sulfur dioxide by ozone on calcium carbonate, Atmos. Chem. Phys., 11, 65936605, doi:10.5194/acp-11-6593-2011, 2011.

Yamaguchi, T., Jin, T., and Tanabe, K.: Structure of acid sites on sulfur-promoted iron oxide, J. Phys. Chem., 90, 3148-3152, 1986.

Zhang, X., Zhang, G., Chen, J., Wang, Y., Wang, X., An, Z., and Zhang, P.: Heterogeneous reactions of sulfur dioxide on typical mineral particles, J. Phys. Chem. B, 110, 12588-12596, 2006. 
Zhang, Q. J., Wang, X., Chen, J. M., and Zhuang, G. S.: Formation of $\mathrm{Fe}$ (II) (aq) and sulfate via heterogeneous reaction of $\mathrm{SO}_{2}$ with $\mathrm{Fe}_{2} \mathrm{O}_{3}$, Chem. J. Chinese U., 7, 1347-1350, 2007.

Zhu T., Shang J., and Zhao D. F.: The roles of heterogeneous chemical processes in the formation of an air pollution complex and gray haze, Sci. China Chem., 54, 145-153, 2011.

Zhu, X. R., Prospero, J. M., and Millero, F. J.: Diel variability of soluble Fe (II) and soluble total Fe in North African dust in the trade winds at Barbados, J. Geophys. Res., 102, 21297-21306, 1997.
Zhuang, G., Yi, Z., Duce, R. A., and Brown, P. R.: Link between iron and sulphur cycles suggested by detection of $\mathrm{Fe}$ (II) in remote marine aerosols, Nature, 355, 537-539, 1992.

Zhuang, G. S., Guo, J. H., Yuan, H., and Zhao, C. Y.: The compositions, sources, and size distribution of the dust storm from China in spring 2000 and its impact on the global environment, Chinese Sci. Bull., 46, 895-901, 2001. 